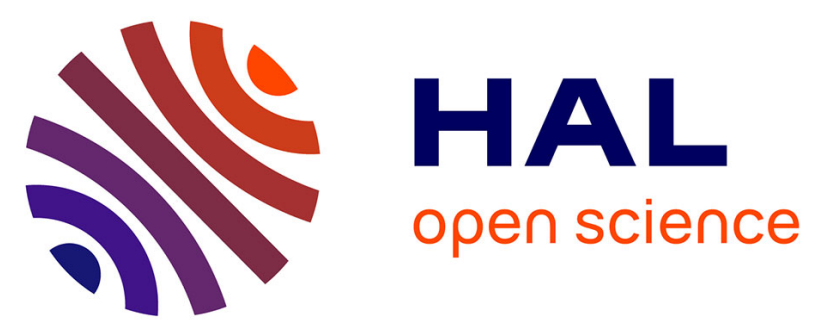

\title{
Time-dependent displacements during and after the April 2007 eruption of Piton de la Fournaise, revealed by interferometric data
}

Jean-Luc Froger, Vincent Famin, Valérie Cayol, Aurélien Augier, Laurent Michon, Jean-François Lénat

\section{To cite this version:}

Jean-Luc Froger, Vincent Famin, Valérie Cayol, Aurélien Augier, Laurent Michon, et al.. Timedependent displacements during and after the April 2007 eruption of Piton de la Fournaise, revealed by interferometric data. Journal of Volcanology and Geothermal Research, 2015, 296, pp.55-68. 10.1016/j.jvolgeores.2015.02.014 . hal-01172390

\author{
HAL Id: hal-01172390 \\ https://hal.science/hal-01172390
}

Submitted on 22 Oct 2017

HAL is a multi-disciplinary open access archive for the deposit and dissemination of scientific research documents, whether they are published or not. The documents may come from teaching and research institutions in France or abroad, or from public or private research centers.
L'archive ouverte pluridisciplinaire HAL, est destinée au dépôt et à la diffusion de documents scientifiques de niveau recherche, publiés ou non, émanant des établissements d'enseignement et de recherche français ou étrangers, des laboratoires publics ou privés. 


\title{
Time-dependent displacements during and after the April 2007 eruption of Piton de la Fournaise, revealed by interferometric data
}

\author{
Jean-Luc Froger ${ }^{\mathrm{a}, *}$, Vincent Famin ${ }^{\mathrm{b}}$, Valérie Cayol a,c , Aurélien Augier ${ }^{\mathrm{a}}$, Laurent Michon ${ }^{\mathrm{b}}$, Jean-François Lénat ${ }^{\mathrm{a}}$ \\ a Laboratoire Magmas et Volcans, Université Blaise Pascal - CNRS - IRD, OPGC, 5 rue Kessler, 63038 Clemmont-Ferrand, France

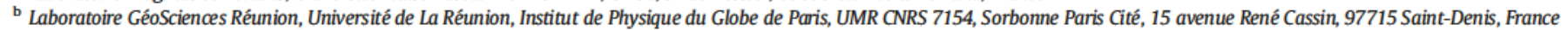 \\ c Université de Lyon, Université Jean Monnet, 23 rue du Docteur Paul Michelon, 42023 Saint Etienne, France
}

\begin{abstract}
A B S T R A C T
From March 30 to May 1 2007, Piton de la Fournaise, La Réunion Island, experienced a major eruptive crisis, characterized by the largest emitted lava volume $\left(210 \times 10^{6} \mathrm{~m}^{3}\right)$ of the 20 th and 21 st centuries, and by a $340 \mathrm{~m}$ deep caldera collapse. The event was captured by InSAR data from the ENVISAT and ALOS- 1 satellites. From this data, we computed the EW and vertical components of the displacement that occurred on the entire edifice during the co-eruptive period and in the following months. Our results reveal unusually large and time-dependent displacements of the Central Cone and the Eastern Flank of Piton de la Fournaise, both of which continued to deform for at least a year after the end of the eruption. The analysis of InSAR displacement combined with other geophysical and field observations allows us to propose conceptual models to explain the Central Cone and the Eastern Flank displacements. We propose that the April 2007 caldera collapse induced a sudden decompression of the hydrothermal system, which had been previously pressurized and heated by temporary sealing of its upper part. This sudden decompression resulted in a strong centripetal subsidence. This then decreased exponentially as poro-elastic compaction and creep of the Central Cone propagated from the collapsed rock column to more distal parts of the hydrothermal system. For the Eastern Flank, we propose that the displacement is related to an intrusion within the Grandes Pentes. While propagating to the surface, the intrusion may have encountered a pre-existing structural discontinuity, intruded it and activated it as a detachment surface. It is likely that the detachment slip, by reducing the minimum principal stress dose to the summit, allowed the injection of the dyke that fed the brief March 30-31 eruption. Then it may have promoted the migration of magma from the main magma storage zone, beneath the Central Cone, to the distal April 2 eruption site. The EW extensional stress field resulting from the slip of the detachment during the co-eruptive period may have activated a set of normal faults on which aseismic creep controlled the response of the edifice during the post-eruptive period.
\end{abstract}

\section{Introduction}

The development of spatial geodetic techniques has brought about considerable advances in the monitoring and interpretation of ground surface displacement in volcanic settings over the last few decades (Dzurisin, 2007). Several studies have looked at static displacements occurring as an immediate response to stress variation, resulting either from the infilling or emptying of a magma source in the upper crust (Pritchard and Simons, 2002; Froger et al., 2007) or from propagation of a magmatic intrusion to the surface (Sigmundsson et al., 1999; Froger et al., 2004; Fukushima et al., 2005, 2010). Time-dependent displacement has also been observed in relation to deep intrusions embedded in a visco-elastic (Newman et al., 2006; Fialko and Pearse, 2012) or elastoplastic crust (Trasatti et al., 2005), pressurization or depressurization of

\footnotetext{
* Corresponding author. Tel.: +334733467 69, +334774851 18; fax: +33473 346744.

E-mail address: J.L.Froger@opgc.univ-bpdermont.fr (J.-L Froger).
}

hydrothermal systems (Rinaldi et al., 2010), volcano-tectonic processes (Palano et al., 2009; Montgomery-Brown et al., 2011), or compaction and loading of lava flows (Stevens et al., 1997).

In this paper, we look at both static and time-dependent ground surface displacements recorded at Piton de la Fournaise (La Réunion hotspot, Fig. 1a-b) during and after the March 30 to May 1, 2007 eruptions.

Piton de la Fournaise has been extensively monitored since 1980 by ground surface displacements (GPS, Electronic Distance Measurement, and tiltmeters) and seismic monitoring networks operated by the Observatoire Volcanologique du Piton de la Fournaise (OVPF). In 2007, the GPS network was composed of 12 continuous GPS stations (Fig. 1c) recording ground surface displacements at $30 \mathrm{~s}$ intervals (Staudacher et al., 2009). Piton de la Fournaise is also one of the few volcanoes in the world to be monitored on a regular basis, since 1998, by Interferometric Synthetic Aperture Radar (InSAR) data. Thirty of the 39 eruptions that occurred during the 1998-2010 period were imaged using data provided by the Canadian RADARSAT-1 satellite (Sigmundsson et al., 1999; Fukushima et al., 2010), the European ASAR-ENVISAT satellite (Froger et al., 2004; 


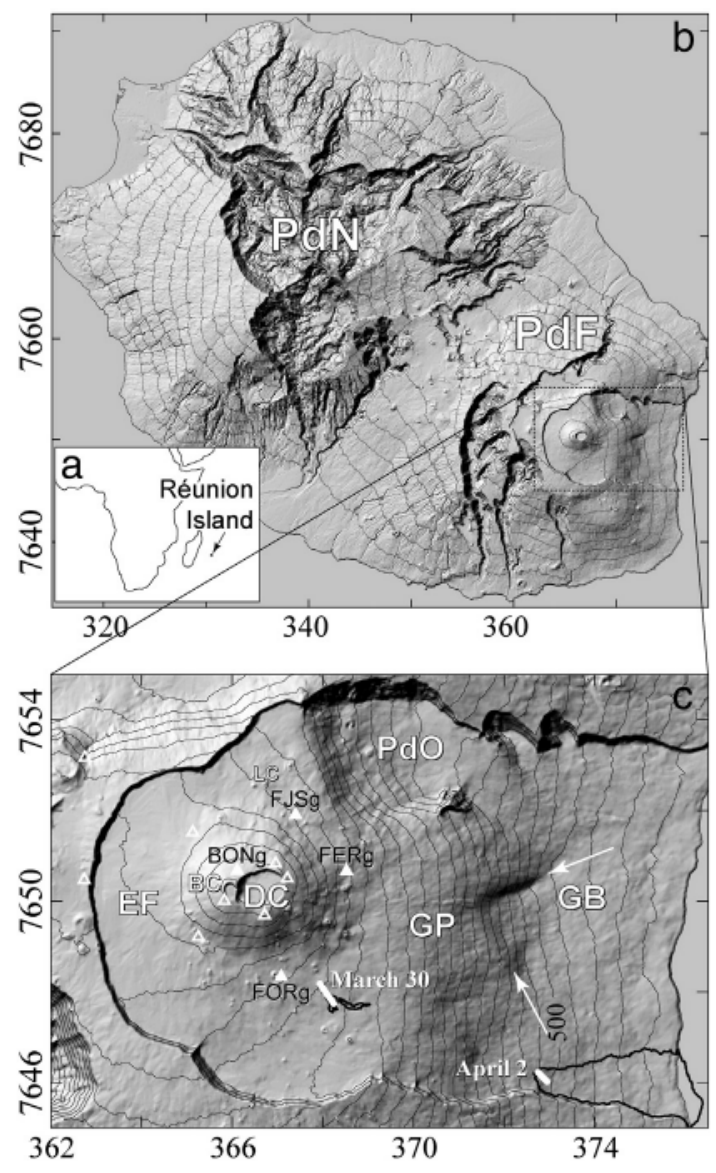

Fig. 1. a) Location of La Réunion Island in the Indian Oœan. b) Location of Piton des Neiges $(\mathrm{PdN})$ and Piton de la Fournaise (PdF) volcanoes. c) Topography of Piton de la Fournaise with 100 m elevation contours and location of the main places discussed in text (BC: Bory Crater; DC: Dolomieu Crater; EF: Endos Fouqué; GB: Grand Brûlé; GP: Grandes Pentes; LC: Langlois Cone; PdO: Plaine des Osmondes). White triangles indicate the locations of the OVPF GPS permanent stations (filled white triangles indicate the location of GPS stations discussed in text). White arrows indicate the Michon and Saint-Ange (2008) V-shaped structure. The locations of the March 2007 and April 2007 eruptive fissures are indicated by straight white lines, while the lava flow contours are in black. Coordinates are in km UTM ( 40 zone south).

Tinard, 2007), the Japanese PALSAR-ALOS satellite (Augier et al., 2008), the German TerraSAR satellite (Froger et al., 2011) and the Italian Cosmo-SkyMed satellites (Bato et al., 2013).

While the OVPF's GPS monitoring network, concentrated in the vicinity of the Central Cone (Fig. 1c), gives an excellent record of the evolution of summit displacement that occurred in March-April 2007, it does not provide any constraint on the displacement field over the whole edifice. Using the various acquisition geometries and sensitivities provided by the C-band ( $5.6 \mathrm{~cm}$ wavelength) ASAR and the L-band (23.6 cm wavelength) PALSAR data, we computed the EW and vertical components of the ground surface displacements which occurred over the entire edifice during the March-April 2007 eruptions and in the following months. Our results reveal unusually large and time-dependent displacements of the Central Cone and the Eastern Flank of Piton de la Fournaise, which both continued to deform for at least a year after the end of the eruption. The characterization of such large timedependent displacement has essential implications not only for risk assessment at the Piton de la Fournaise volcano, but also for the understanding of deformation processes related to magma transfer in general.

\section{Geological setting}

The Piton de la Fournaise volcano forms the SE half of La Réunion, an oceanic basaltic island in the southernmost part of Mascarene Basin
(Indian Ocean), 800 km east of Madagascar (Fig. 1a-b). Most historical eruptions of Piton de la Fournaise occurred in the Enclos FouquéGrand Brûlé structure, an EW elongated horseshoe shaped depression $(\sim 13 \times 10 \mathrm{~km})$ opened eastward to the Indian Ocean (Fig. 1c). Among other hypotheses, it has been proposed that the Enclos Fouqué-Grand Brûlé structure results from a caldera collapse (Chevallier and Bachelery, 1981; Duffield et al., 1982; Bachèlery and Mairine, 1990; Bachèlery, 1995) or from flank collapses (Lénat et al., 1990; Labazuy, 1996; Lénat et al., 2001). Although the question of the Enclos FouquéGrand Brûlé structure origin is still debated, the presence of debris avalanche deposits offshore of the Piton de la Fournaise Eastern Flank demonstrates the occurrence of flank destabilisations running down slope to the abyssal plain (Lénat et al., 1989; Labazuy, 1996; Le Friant et al., 2011).

In the upper part of the Enclos Fouqué-Grand Brûlé structure, the Central Cone, built up by the accumulation of volcanic products, exhibits an EW elongated shape, with two pit-craters, the Bory crater to the west and the Dolomieu crater to the east. Joint analyses of ground surface displacements, seismicity and petrology-geochemistry of the lavas have led different authors to infer the presence of a main magma storage zone beneath the Central Cone between 0 and $1000 \mathrm{~m}$ above sea level (Lénat and Bachèlery, 1990; Peltier, 2007; Peltier et al., 2009a; Prôno et al., 2009). However, the exact depth, volume and shape of this storage zone are still under debate, as well as the presence of only one or several separate storage units.

After an unusually long period of 63 months rest, on March 1998, Piton de la Fournaise began a new period of activity, characterized by an average rate of 2.7 eruptions per year until the December 2010 eruption. During this period, in most cases the eruptive fissures opened in the summit crater of the Central Cone or occurred directly on the flank of the Central Cone. Exceptionally, fissures opened at low elevation far from the central cone in the Plaine des Osmondes or in the Grand Brulé (Fig. 1c, Peltier et al., 2009a).

\section{The March-April 2007 eruptions}

The March-April 2007 eruptions were preceded by 10 months of quasi-continuous activity during which 3 summit eruptions took place (July-August 2006, August 2006-January 2007 and February 2007, Peltier et al., 2009a). By the end of this period the Dolomieu crater (Fig. 1c) had become overfilled and lava flows started to spill over the crater rim at its lowest elevation. The first two months of 2007 were marked by a continuous inflation of the both the entire edifice and the Central Cone (Staudacher et al., 2009). Peltier et al. (2009b) interpreted this inflation as evidence of a recharge of the main magma storage zone, generally assumed to exist beneath the Central Cone, between 0 and $1000 \mathrm{~m}$ above sea level (Lénat and Bachèlery, 1990; Peltier, 2007; Peltier et al., 2009a; Prôno et al., 2009). A deeper source of inflation was recently proposed from the RER far field very broadband seismic station (Fontaine et al., 2014). Whatever the source's depth, the March-April 2007 eruptions were heralded by a progressive increase in seismicity beneath the summit zone from the end of February to the end of March. On March 30, at 18:50 GMT an eruptive fissure opened at $1900 \mathrm{~m}$ above sea level at the southeastern base of the Central Cone (Staudacher et al., 2009). The fissure fed a small lava flow $\left(<10^{6} \mathrm{~m}^{3}\right.$, Staudacher et al., 2009, Fig. 1c) of aphyric basalt during an initial, $\sim 10$-hour-long, eruptive phase. On April 2 a new eruptive fissure opened $7 \mathrm{~km}$ away from the summit on the lower Eastern Flank ( $\sim 600 \mathrm{~m}$ above sea level, Fig. 1c), also emitting aphyric basalt. From April 5, the OVPF seismic and GPS networks recorded a significant increase in activity below the Central Cone (Michon et al., 2007). The crisis climax was reached in the night between April 5 and 6 with the onset of the collapse of the Dolomieu crater. At the same time, a significant increase in eruptive activity was observed at the lower Eastern Flank eruptive fissure, together with an evolution of lava composition toward oceanite (Di Muro et al., 2014). The eruption continued until May 1 with 
a continuous lava emission at the Eastern Flank fissure. Considering the total emitted volume of lava $\left(210 \times 10^{6} \mathrm{~m}^{3}\right.$, Bachèlery et al., 2010) and the magnitude of the Dolomieu collapse (340 $\mathrm{m}$ in depth, 100 $120 \times 10^{6} \mathrm{~m}^{3}$ in volume, Michon et al., 2007; Urai et al., 2007), the April 2007 crisis can be regarded as the largest eruption ever observed at Piton de la Fournaise during the XXth and XXIst centuries.

After the end of the March-April eruptions, no further magmatic activity occurred for about 500 days and only 8 minor summit eruptions ( with emitted volume of magma generally lower than $10^{6} \mathrm{~m}^{3}$ ) have occurred since. This suggests that the system was significantly modified by the April 2007 events.

\section{Data processing}

\subsection{Computation of the interferograms}

We processed two separate interferometric datasets spanning the co-eruptive period (i.e. the period including the March 30 eruption, the April 2 eruption and the April 6 caldera collapse) and the posteruptive period (i.e. from May 2007 to September 2008) respectively.

For the co-eruptive period, we calculated 2 ascending PALSAR interferograms (Fig. 2a-b, Table 1), 2 ascending and 2 descending ASAR interferograms (Fig. 3a-d, Table 1).

For the post-eruptive period, we calculated 6 ascending PALSAR interferograms (Online Resource 1) and 129 ASAR interferograms from ascending and descending viewing directions (Online Resource 2).

All interferograms (PALSAR and ASAR) were produced with the DIAPASON@ software (CNES/Altamira-Information, 1996) using the two-pass method described by Massonnet and Feigl (1998). The contribution of the orbital trajectories in the ASAR interferograms was modelled and removed using the ESA DORIS orbit state vectors. We used a 25 m Digital Elevation Model (DEM) made by the French Geographic Institute (IGN) to model and remove the topographic contribution. The IGN DEM was also used to provide a geographic frame (UTM-WGS84) for the interferometric products.

\subsection{Computation of the early co-eruptive displacement}

Both PALSAR interferograms displayed in Fig. 2a-b and the three ASAR interferograms displayed in Fig. 3a-c recorded "early co-eruptive displacement" related to the early phase of the March-April eruptions, including the March 30 intrusion at the southeastern base of the Central Cone, the opening of the April 2 vent at $600 \mathrm{~m}$ a.s.l. on the lower Eastern Flank and the April 5-April 9 Dolomieu collapse. In addition to these early co-eruptive displacements, the second PALSAR interferogram (Fig. 2b) also recorded the displacement that occurred during the last phase of the eruption, although the largest displacement is expected to have occurred during the early phase. The descending ASAR interferogram displayed in Fig. 3d spans the April 4-May 11, 2007 period (i.e. 35 days). As the second PALSAR interferogram, it recorded displacement that occurred during the last days of the March-April eruption.

Due to their similar lines-of-sight (LOS, Table 1), the PALSAR interferograms and the two ascending ASAR interferograms exhibit very similar patterns of displacement. However, because of the longer wavelength of PALSAR ( 1 interferometric fringe $=11.8 \mathrm{~cm}$ of displacement in the LOS direction) with respect to ASAR (1 interferometric fringe $=2.8 \mathrm{~cm}$ of displacement in the LOS direction), the same displacement produces $\sim 4$ times less fringes in the PALSAR interferograms. This characteristic is advantageous where large strain occurs (greater than $\sim 3 \mathrm{~mm} \cdot \mathrm{m}^{-1}$ ) which might produce spatial aliasing of the interferometric fringes in the ASAR interferograms, whereas the PALSAR interferograms remain coherent as long as the strain does not exceed $\sim 13 \mathrm{~mm} \cdot \mathrm{m}^{-1}$ (Massonnet and Feigl, 1998). As a matter of fact, the loss of coherence on the ASAR interferograms in the Grandes Pentes, particularly severe on the swath 6 descending interferogram (Fig. 3c), is most likely caused by aliasing of the interferometric fringes. In contrast, the PALSAR interferograms exhibit a remarkable coherence, not only over the areas affected by large strain but also over the vegetated areas of the volcano flanks (Fig. 2a-b). Similarly, the Dolomieu crater is incoherent on the four ASAR interferograms and on both PALSAR interferograms as the magnitude of the April 5-6 collapse, at the summit of the Central Cone, greatly exceeds the theoretical limit of maximum detectable strain.

The co-eruptive interferograms show complex displacement patterns that reflect the superimposition of different signals. The characterisation of the individual signals is difficult to obtain from the interferograms, as each of them provides only a projection of the ground surface displacement in a specific LOS of the satellite. We obtained a more discriminating dataset by constructing maps of displacement components (EW, NS, and vertical) from the independent co-eruptive interferograms using the following formulation (Wright et al., 2004):

$\hat{u}=-\left[P^{\tau} \times \Sigma_{R}^{-1} \times P\right]^{-1} \times P^{\tau} \times \Sigma_{R}^{-1} \times R$

where $\hat{u}$ is the column vector containing the EW, NS and vertical components of displacement, $P$ is the matrix containing the LOS unit vector for the independent co-eruptive interferograms, $R$ is the column vector containing the displacements measured from the independent co-eruptive interferograms (obtained after unwrapping and scaling by the radar

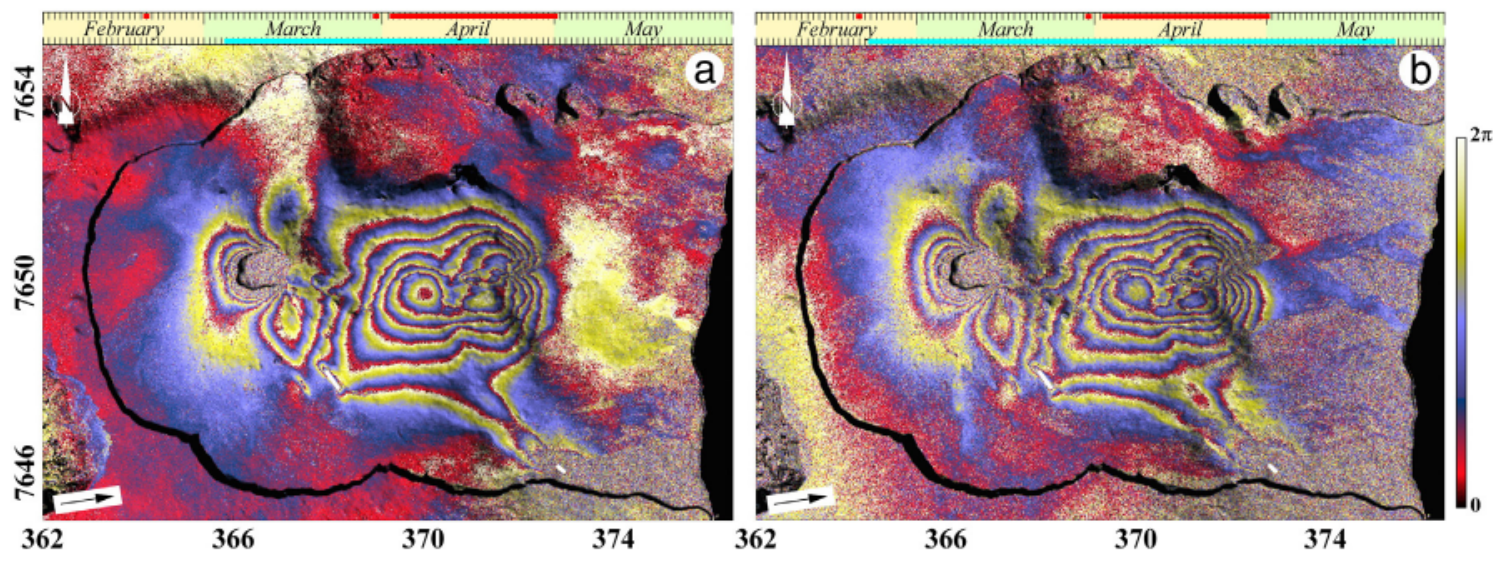

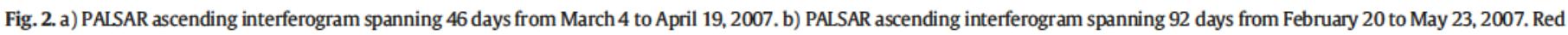

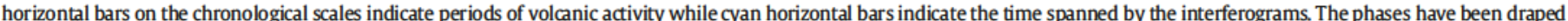

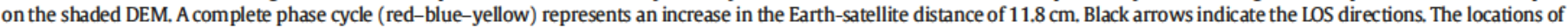

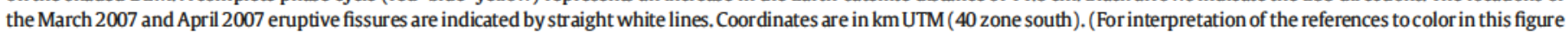
legend, the reader is referred to the web version of this article.) 
Table 1

Parameters of the six co-eruptive interferograms.

\begin{tabular}{|c|c|c|c|c|c|c|}
\hline & Interferogram 1 & Interferogram 2 & Interferogram 3 & Interferogram 4 & Interferogram 5 & Interferogram 6 \\
\hline SAR/wavelength & PALSAR/23.5 cm & PALSAR/23.5 cm & ASAR/5.63 cm & ASAR/ $5.63 \mathrm{~cm}$ & ASAR/ $5.63 \mathrm{~cm}$ & ASAR/ $5.63 \mathrm{~cm}$ \\
\hline Pass & Ascending & Ascending & Ascending & Ascending & Descending & Descending \\
\hline Swath-track ${ }^{\mathrm{a}}$ & 539 & 541 & $2-313$ & $5-399$ & $5-048$ & $6-277$ \\
\hline Incidence angle $^{\mathrm{b}}$ & $37.8^{\circ}$ & $44.4^{\circ}$ & $22.8^{\circ}$ & $37.6^{\circ}$ & $37.7^{\circ}$ & $41^{\circ}$ \\
\hline Unit Vector [East, North, Up] ${ }^{\mathrm{c}}$ & {$[-0.59,-0.15,0.79]$} & {$[-0.68,-0.17,0.70]$} & {$[-0.38,-0.08,0.92]$} & {$[-0.59,-0.14,0.79]$} & {$[0.57,-0.13,0.80]$} & {$[0.64,-0.15,0.75]$} \\
\hline Orbit-date 1 & $05903-04 / 03 / 2007$ & $05728-20 / 02 / 2007$ & $26419-20 / 03 / 2007$ & $26505-26 / 03 / 2007$ & $26655-06 / 04 / 2007$ & $26383-18 / 03 / 2007$ \\
\hline Orbit-date 2 & $06574-19 / 04 / 2007$ & $07070-23 / 05 / 2007$ & $26920-24 / 04 / 2007$ & $27006-30 / 04 / 2007$ & $27156-11 / 05 / 2007$ & $26884-22 / 04 / 2007$ \\
\hline $\mathrm{h}_{\mathrm{a}}{ }^{\mathrm{d}}(\mathrm{m})$ & -1705 & 94 & -23 & -66 & 126 & -75.5 \\
\hline
\end{tabular}

a The swath is defined only for ASAR data.

b From the vertical.

c Line Of Sight (LOS) unit vector from ground to satellite at midswath for the Piton de la Fournaise latitude.

d The altitude of ambiguity $h_{a}$ gives an estimate of the sensitivity of the interferogram to the topography.

half-wavelength) and $\Sigma_{R}$ is the covariance matrix for errors in the measured displacements, where the off-diagonal terms are set to 0 and the diagonal terms correspond to the local variance of the interferograms. In practise, the near-polar orbits of the ENVISAT and ALOS satellites prevent the NS component of displacements from being resolved to an acceptable accuracy. Therefore, we base our analysis of displacement on the EW and vertical components only.

A prerequisite step to the determination of the 3D displacement components is the unwrapping of the interferograms. Due to their excellent coherence, both PALSAR interferograms were successfully unwrapped without any particular difficulty using the Snaphu algorithm (Chen and Zebker, 2002). However, the strong fringe aliasing affecting the two ascending and the swath 6 descending ASAR interferograms in the Grandes Pentes (Fig. 3a-c) called for a specific procedure to obtain reliable unwrapped phases. The first step was to generate a map of the large scale co-eruptive displacement, projected in an arbitrary ascending LOS, by low-pass filtering the unwrapped phases of the first PALSAR interferogram (Fig. 2a) that spans a period close to the ones spanned by the two ASAR interferograms (Table 1). We scaled and removed this large scale displacement from the ascending ASAR interferograms, thus reducing their aliasing. We then used Snaphu to unwrap the residual phases and we added back the large scale displacement to the results of the unwrapping. In this way we achieved a significantly improved unwrapping of the two ascending ASAR interferograms compared to the simple pass Snaphu procedure. The second step was to use three of the ascending unwrapped interferograms to retrieve a rough estimate of the EW and vertical components of displacement. Note that we did not use the second PALSAR
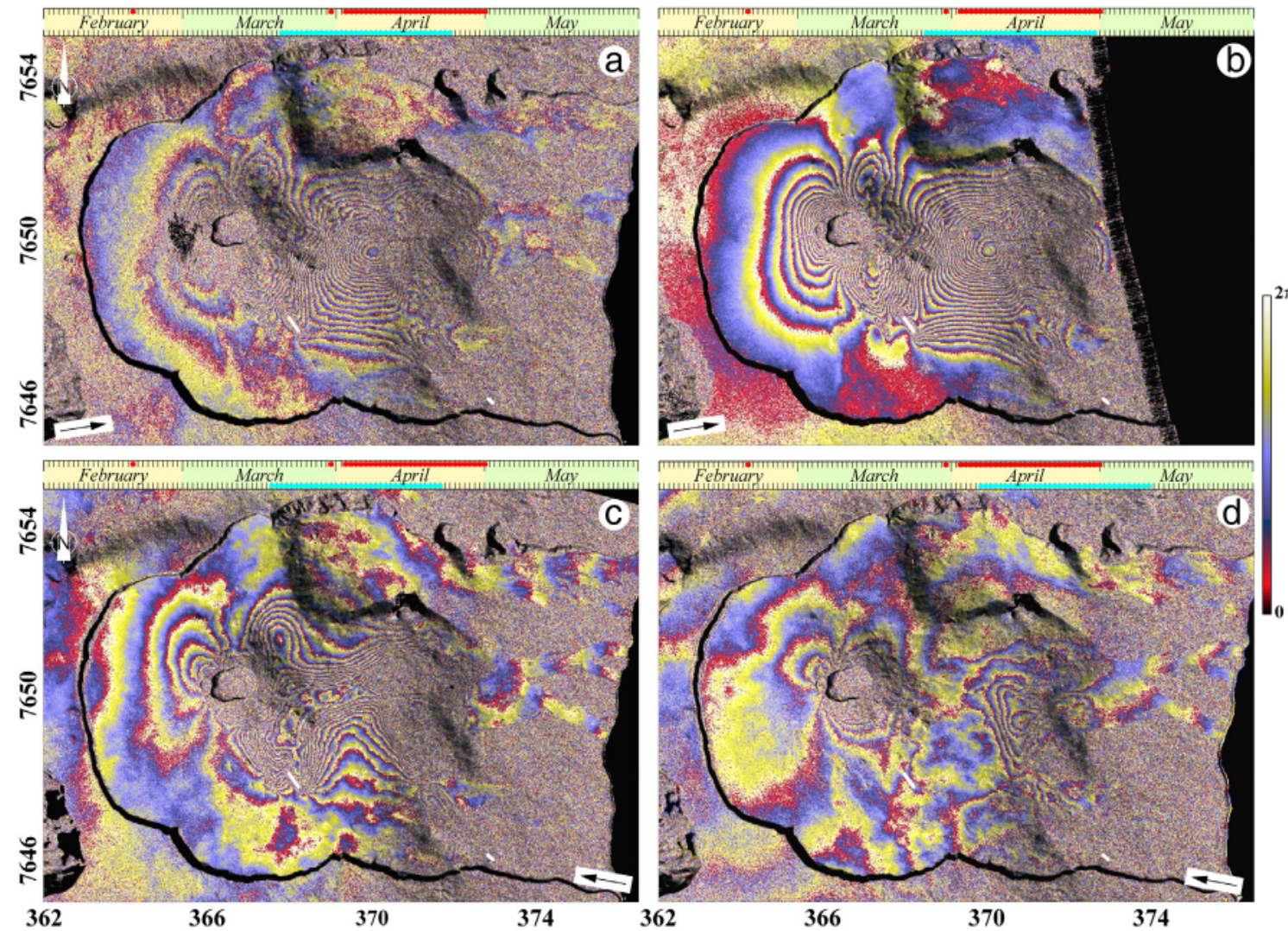

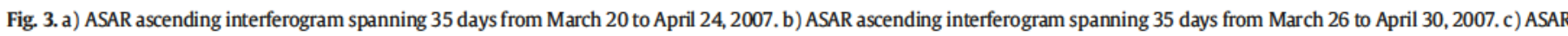

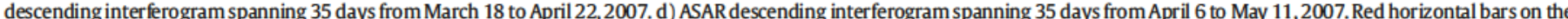

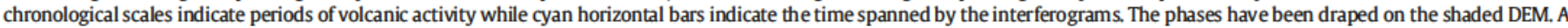

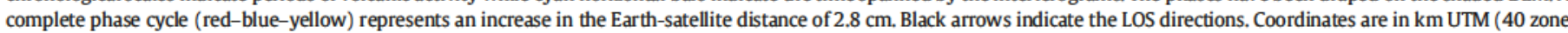
south). (For interpretation of the references to color in this figure legend, the reader is referred to the web version of this article.) 
interferogram (Fig. 2b) in this step as it spans a significantly longer period than the three other ascending interferograms and possibly recorded significantly different displacements. Then, we low-pass filtered and projected these estimated displacements in the LOS corresponding to swath 6 descending ASAR interferogram, in order to generate a map of the large scale component of the co-eruptive displacement in the descending LOS. Although the dilution of precision on the displacement components obtained by combining the three ascending interferograms is important, we assume that the large scale displacement obtained this way is reliable enough to be used in the same way as for the PALSARderived, large scale displacement. Therefore, we removed it from the descending ASAR interferogram, we unwrapped the residual phases and added back the large scale component to the results of unwrapping. Actually, although removal of the large scale component indisputably reduced the aliasing of the swath 6 descending interferogram in some areas of the Grandes Pentes, some other areas remain incoherent and were not unwrapped successfully.

After unwrapping, we detrended the interferograms in order to reference them to a common zero phase origin and to remove residual orbital component. We then obtained the EW and vertical displacement components using Eq. (1).

Unwrapping errors corrupt the inverted displacements locally. Other sources of error, affecting individual interferograms, such as atmospheric noise, topographic residuals or displacement occurring outside of the common period shared by the entire co-eruptive InSAR dataset, might also contribute to the corruption of the result of the components inversion. For this reason, we discarded the track 541 PALSAR interferogram and the swath 5 descending ASAR interferogram for the determination of the components of early co-eruptive displacement. We estimated the quality of the inverted displacements on a pixel-bypixel basis using the total standard error as formulated by Strang (1986) (see Online Resource 3). We used the resulting standard error map, combined with an image of the mean coherence of the five coeruptive interferograms, to create a mask where all pixels in the area of interest (Enclos Fouqué, Grandes Pentes) with a standard error higher than $0.07 \mathrm{~m}$ or a mean coherence lower than $25 \%$ are masked. Then we interpolated all the masked areas whose size did not exceed $5 \times 5$ pixels from neighbouring pixels. The interpolation was done using a Kriging algorithm (Journel and Huijbregts, 1978).

\subsection{Computation of late co-eruptive displacement}

We used a three-step procedure to compute the "late co-eruptive displacement" which occurred in the last 10 days of the March-April eruption. First we projected the EW and vertical components of the early co-eruptive displacement in the LOS of the ascending track 541 PALSAR interferogram. We thus obtained a synthetic track 541 PALSAR interferogram in which phases are supposed to record only the early co-eruptive displacement. We subtracted this synthetic interferogram from the actual one to get phase changes, in track $541 \mathrm{LOS}$, corresponding to the last days of the eruption. Finally we use the resulting residual interferogram, together with the descending swaths/tracks 5/048 ASAR interferogram, to retrieve the EW and vertical components of late co-eruptive displacements, using Eq. (1).

In contrast to the early co-eruptive displacements, we were not able to produce a standard error map for the components of the late co-eruptive displacement since the interferometric dataset used for the determination of these components does not provide any geometric redundancy. In addition to the noise sources already mentioned above, it is obvious that our way of estimating the components of late coeruptive displacement implies propagation of early co-eruptive displacement errors to late co-eruptive displacement. As a consequence, we use the maps of EW and vertical late co-eruptive displacement only for qualitative interpretation without any attempt to numerically model them.

\subsection{Computation of post-eruptive displacement}

The ASAR and PALSAR interferograms covering the one and a halfyear period of quiescence after the end of the March-April 2007 eruptions show that the ground surface displacement continued for at least one year, with decreasing amplitude, both at the Central Cone and in the Grandes Pentes. In order to characterize this displacement, we calculated their EW and vertical components using the following approach. First, we selected the five ASAR swaths providing the largest set of interferograms with the most regular distribution over the posteruptive period (i.e. ascending swaths/tracks 2/313, 5/399 and 7/170 and descending swaths 6/277 and 7/005, Online Resource 2). From each selected interferograms set, we generated time series of LOS displacement (i.e. a LOS displacement map for each SAR image acquisition epoch) using the technique proposed by Lundgren and Usai (2001). From each time series, we extrapolated a cumulative LOS displacement map spanning exactly the same one-year time period (May 2007-May 2008). Finally, we used these five extrapolated maps to compute the EW and vertical components of displacements using Eq. (1). The quality of the resulting displacement components was estimated using the same approach as employed for the early co-eruptive displacement components.

\section{Results}

\subsection{Early co-eruptive displacement}

The early co-eruptive EW and vertical components of displacement show four main signals (Fig. 4a-b). (1) The western part of the Central Cone is affected by both eastward and downward displacements indicating a centripetal subsidence (Ec1 in Fig. 4c) reaching a maximum of $50 \mathrm{~cm}$ at the NW rim of the Dolomieu crater. (2) The eastern flank of the Central Cone develops a large NS-trending inflation axis of about $4 \mathrm{~km}$ between the Langlois cone and the location of the March 30 eruptive fissure (Ec2 in Fig. 4c). The horizontal displacement (Fig. 4a) is oriented eastward on the eastern side of the axis and westward on the western side, for a total displacement difference between the east and the west of up to $20 \mathrm{~cm}$ to the north of the Central Cone and up to $45 \mathrm{~cm}$ to the south of the Central Cone. The vertical displacement shows a maximum uplift of about $25 \mathrm{~cm}$ to the southeast of the Central Cone. This asymmetric displacement pattern is typical of a dyke intrusion (Pollard et al., 1983), as previously observed with InSAR data at Piton de la Fournaise and elsewhere (Jónsson et al., 1999; Sigmundsson et al., 1999; Froger et al., 2004; Fukushima et al., 2010). The large scale of displacement suggests a relatively deep source along most of its length. At its southern end, the NS axis divides into two $\mathrm{N} 150^{\circ} \mathrm{E}$ branches and the scale of displacement becomes shorter, suggesting that the source of the displacements becomes shallower (Ec2a and Ec2b in Fig. 4c). The easternmost branch (Ec2b in Fig. 4c) coincides with the location of the March 30 eruptive fissure, indicating that the displacement axis is related to the March 30 dyke intrusion. Given the displacement pattern orientation, the dyke is more likely oriented NS rather than $\mathrm{N} 125^{\circ} \mathrm{E}$ as proposed earlier (Fig. 14 in Peltier et al., 2009b). (3) To the east, between the foot of the Central Cone and the base of the Grandes Pentes, a wide zone undergoes large displacements. On the horizontal component map, the pattern is fan-shaped and covers an area of about $14 \mathrm{~km}^{2}$ in the Grandes Pentes, indicating an extensive eastward displacement with a maximum of up to $1.4 \mathrm{~m}$ (Ec3 in Fig. 4c). The vertical displacement map has a more complicated pattern, with a general subsidence of the Grandes Pentes, of up to $33 \mathrm{~cm}$, intersected in its central part by a $\sim \mathrm{N}^{\circ} 70^{\circ} \mathrm{E}$ trending uplift reaching $37 \mathrm{~cm}$ (Ec4 in Fig. 4c). These observations indicate that a large scale downslope displacement of the Grandes Pentes occurred, accompanied by a shorter scale uplift of its central part. The mean ratio of horizontal to vertical displacements, calculated after masking the uplifting area, is $\sim 4$, suggesting that the displacement occurred on a surface roughly parallel to the mean local slope $\left(\sim 15^{\circ}\right.$, see also the profile of the displacement 

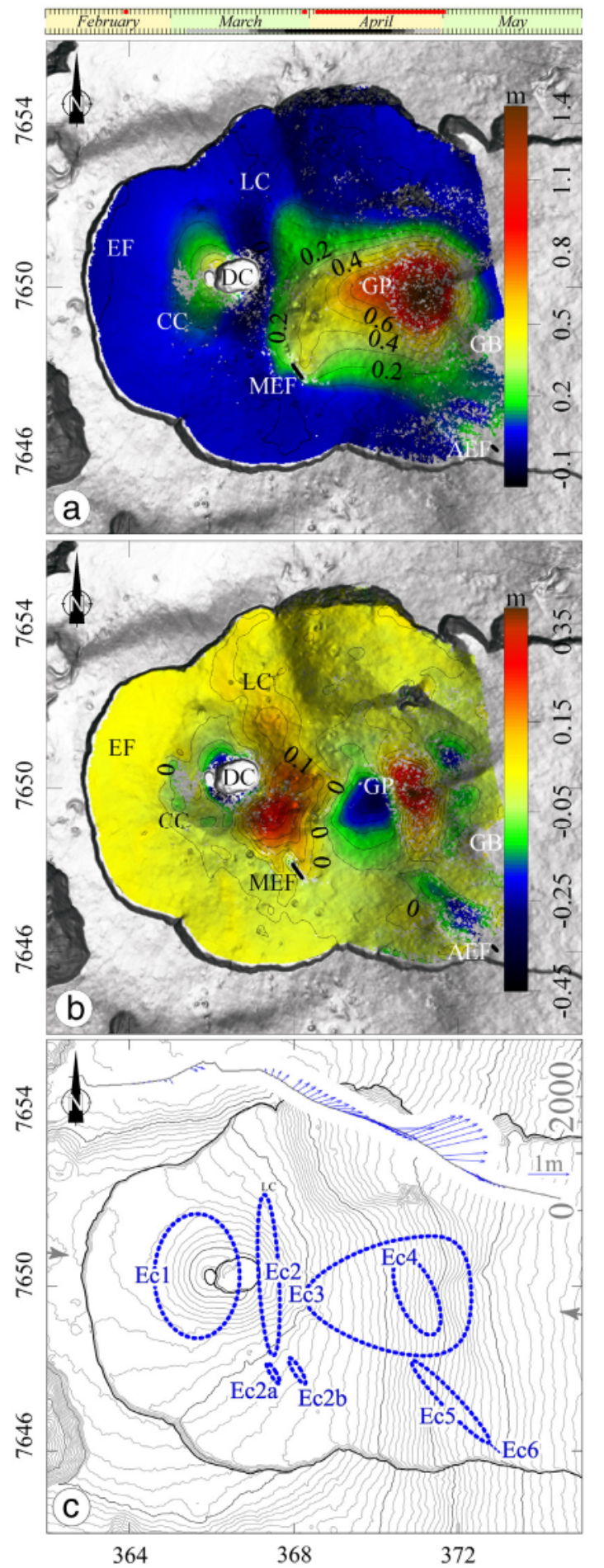

Fig. 4. Early co-eruptive displacements draped on the shaded DEM. a) EW component, contour level interval is $0.1 \mathrm{~m}$. b) Vertical component, contour level interval is $0.05 \mathrm{~m}$. c) Sketch map of the main displacement patterns (blue dashed lines) referred to as Ec1 to Ec6. Grey arrows point to the extremities of the profile of the displacement vectors shown in the upper part of the figure. Thick bladk lines in a) and b) indicate the location of eruptive fissures. AEF: April 2, 2007 eruptive fissure; MEF: March 30, 2007 eruptive fissure; CC: Central Cone; EF: Enclos Fouqué; GB: Grand Brûlé; GP: Grandes Pentes; LC: Langlois Cone. Coordinates are in km UTM (40 zone south). Chronological scale at the top of the figure indicates the periods of eruptive activity (in red) and the period spanned by the displacement map (in black the period common to the entire InSAR dataset used for the displacement calculation, in grey the period spanned only by a part of the InSAR dataset). (For interpretation of the references to color in this figure legend, the reader is referred to the web version of this article.) vectors on Fig. 4c). On the other hand, it is noteworthy that the maximum displacement affects the area with the steepest slopes in the Grandes Pentes $\left(\sim 20^{\circ}\right.$, see also the profile of the displacement vectors on Fig. 4c). (4) At the SE base of the Grandes Pentes there is a $N 125-130^{\circ} \mathrm{E}$ trending subsidence axis with a maximum value of $28 \mathrm{~cm}$ on the vertical displacement map (Ec5 in Fig. 4c). The displacement is smaller $(\sim 15 \mathrm{~cm})$ on the horizontal displacement map, and consists of a N125- $130^{\circ} \mathrm{E}$ axis of westward displacement bracketed by two $\mathrm{N} 125-130^{\circ} \mathrm{E}$ axes of eastward displacement. The SE end of the subsidence axis is not well defined as it ends in an area of very low interferogram coherence. Actually, this area coincides with the location of the April 2 eruptive fissure (Ec6 in Fig. 4c), suggesting that the $\mathrm{N} 125-130^{\circ} \mathrm{E}$ displacement axis is related to the magma migration toward the April 2 eruption vent.

\subsection{Late co-eruptive displacement}

The late co-eruptive EW and vertical components of displacement show four main signals (Fig. 5a-b). (1) The Central Cone is affected by centripetal subsidence ( $\mathrm{Lc} 1$ on Fig. $5 \mathrm{c}$ ) producing symmetrical displacement on the horizontal displacement map (eastward on the western flank and westward on the eastern flank, Fig. 5a), and roughly concentric downward displacement on the vertical displacement map (Fig. 5b). (2) The Grandes Pentes display a large trapezoidal eastward displacement pattern (Fig. 5a \& feature Lc2 in Fig. 5c) that partly coincides with the early co-eruptive eastward displacement pattern in the area, although it extends significantly farther to the south. The magnitude of the displacement is between 15 and 20 times lower than that of early co-eruptive displacement (for a roughly similar time span), indicating that most of the eastward displacements in the Grandes Pentes occurred early, during the first days of the eruption. (3) On the vertical displacement map, the central part of the Grandes Pentes displays a triangular subsidence pattern (Fig. 5b \& feature Lc3 in Fig. 5c) that coincides remarkably, in location, with the uplift detected in this area on the vertical component of early co-eruptive displacement (Fig. 4). It is noteworthy that the western edge of this subsidence pattern has $\mathrm{a} \sim \mathrm{N} 155^{\circ} \mathrm{E}$ orientation, close to the orientation of some structural features of Piton de la Fournaise (e.g. the western rampart of the Plaine des Osmondes and the western scarp of the Michon and Saint-Ange (2008) V-shaped structure, see Fig. 1c and shaded grey areas in Fig. 5c). (4) At the southern end of the subsidence pattern, slightly shifted to the east, a $\mathrm{N} 145^{\circ} \mathrm{E}$ subsiding axis is observed on the vertical displacement map (LC4, Fig. 5c). This axis coincides nearly exactly with the Ec5 feature and ends close to the April 2 eruptive fissure.

\subsection{Post-eruptive displacement}

The post-eruptive EW and vertical displacement components (Fig. 6a, b) show essentially the same patterns (summarized on Fig. 6c) as the EW and vertical component maps for the late co-eruptive displacements (Fig. 5). (1) The centripetal subsidence of the Central Cone (P1 in Fig. 6c) produces a symmetrical pattern of displacement on the horizontal displacement map (up to $19 \mathrm{~cm}$ eastward on the western flank and $8 \mathrm{~cm}$ westward on the eastern flank, Fig. 6a) and a concentric displacement on the vertical displacement map (up to $25 \mathrm{~cm}$ downward, Fig. 6b). The pattern of the centripetal subsidence is limited to the Central Cone suggesting a relatively shallow source of displacement. (2) The Grandes Pentes display a large trapezoidal displacement pattern (P2 in Fig. 6c) that roughly coincides with the late co-eruptive displacement pattern in the area. The total area affected by the displacement is up to $20 \mathrm{~km}^{2}$. Contrary to the early co-eruptive period, the displacements are uniformly distributed eastward and downward over the entire zone, indicating an overall downslope motion. The ratio of horizontal to vertical displacements ( 0.45 on average over the entire trapezoidal displacement pattern) is inverse to the value during the early co-eruptive period (see also the profile of the displacement vectors on Fig. 6c). The displacement pattern is limited to the south by a sharp $\mathrm{N} 120-125^{\circ} \mathrm{E}$ limit roughly 

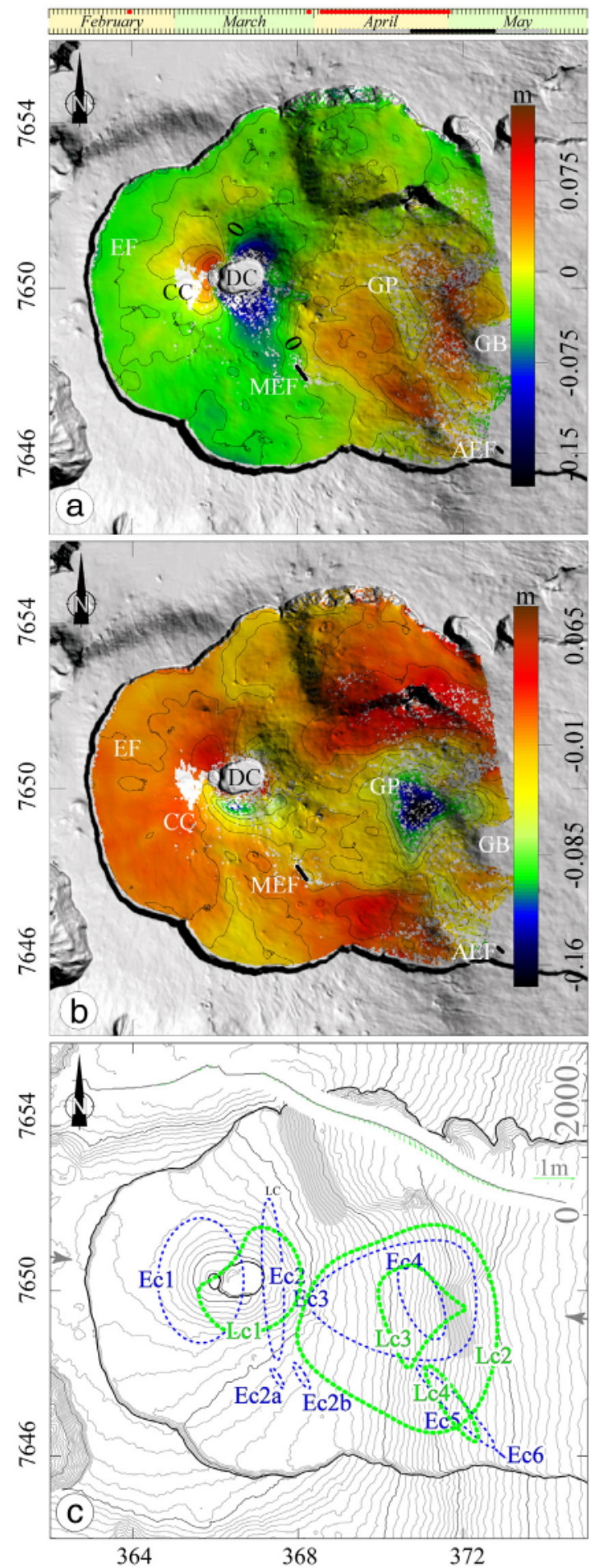

Fig. 5. Late co-eruptive displacements draped on the shaded DEM. a) EW component, contour level interval is $0.02 \mathrm{~m}$. b) Vertical component, contour level interval is $0.02 \mathrm{~m}$ c) Sketch map of the main late co-eruptive displacement patterns (green dashed lines) referred to as Lc1 to LC4, and superimposed onto the main early co-eruptive displacement patterns (blue dashed lines) for comparison. Grey arrows point to the extremities of the profile of the displacement vectors shown in the upper part of the figure. Shaded grey areas: western rampart of the Plaine des Osmondes and western scarp of the Michon and Saint-Ange (2008) $\mathrm{V}$-shaped structure. Thick black lines in a) and b) represent the location of eruptive fissures. AEF: April 2, 2007 eruptive fissure; MEF: March 30, 2007 eruptive fissure; CC: Central Cone; EF: Enclos Fouqué; GB: Grand Brûlé; GP: Grandes Pentes. Coordinates are in km UTM ( 40 zone south). Chronological scale at the top of the figure indicates the periods of eruptive activity (in red) and the period spanned by the displacement map (in black the period common to the entire InSAR dataset used for the displacment calculation, in grey the period spanned only by a part of the InSAR dataset). (For interpretation of the references to color in this figure legend, the reader is referred to the web version of this article.) joining the March 30 and the April 2 eruptive fissures (P3 on Fig. 6c). Similarly as during the co-eruptive period, the displacement does not extend to the Grand Brûle area. The displacement pattern appears to be divided into two compartments by a N65-70 $0^{\circ}$ lineament (P4 feature in Fig. 6c) that coincides with a normal fault previously identified by Michon and Saint-Ange (2008). (3) The central part of the southern compartment is occupied by a NS-elongated subsidence axis (up to $35 \mathrm{~cm}$, P5 in Fig. 6c). This subsidence axis roughly coincides with the southern half of the early co-eruptive NS uplift axis (Ec4 in Fig. 4c) and with the late coeruptive subsidence pattern (LC3 in Fig. 5c). On the EW component map, displacements are asymmetric on both sides of the subsidence axis, with eastward displacements on the western side of the axis and westward displacements on the eastern side indicating an axipetal component to the subsidence. (4) At the southern end of the NS subsidence axis, a $2.5 \mathrm{~km}$ long, $\mathrm{N} 135^{\circ} \mathrm{E}$ narrow subsidence axis (P6 in Fig. 6c), nearly coincident with Ec5 and Lc4 (Figs. $4 \mathrm{c}$ and $5 c$, respectively), ends close to the April 2 eruptive fissure.

\section{Discussion}

Among the different displacement patterns revealed by the InSAR data, both the NS uplift axis, on the eastern flank of the Central Cone (Ec2 in Fig. 4c), and the inflation axis on the central Grandes Pentes (Ec4 in Fig. 4c) are observed only during the early co-eruptive period. On the contrary, the centripetal subsidence of the Central Cone (Ec1, Lc1 and P1 in Figs. 4c, 5c and 6c, respectively) and the large scale downslope displacement of the Grandes Pentes (Ec3, Lc2 and P2 in Figs. 4c, 5c and $6 \mathrm{c}$, respectively) continued long after the eruption. This observation suggests that the first two patterns are associated with the elastic response of the medium to transient co-eruptive processes, while the last two patterns could be associated with persistent processes or alternatively could reflect an inelastic response of the medium to transient processes. In the following subsections we discuss the possible causes of these displacements.

\subsection{Displacement of the Central Cone}

\subsubsection{Co-eruptive subsidence}

Displacement of the Central Cone consists of the superimposition of the NS uplift axis, observed on the eastern flank of the Central Cone only during the early co-eruptive period, and the centripetal subsidence of the Central Cone observed during both co- and post-eruptive periods. The fact that the easternmost branch of the NS uplift axis (Ec2b in Fig. 4c) coincides with the location of the March 30 eruptive fissure strongly suggests that this axis was induced by the March 30 dyke. This interpretation is consistent with the transient character of the displacements. Moreover, the displacement pattern suggests that the March 30 intrusion divided, near to the surface, into two N150 ${ }^{\circ}$ en echelon fissures. While the easternmost fissure reached the surface and emitted a small lava flow, the westernmost fissure remained unnoticed before our study, either because it did not reach the surface or because its manifestation at the surface was too subtle.

As the InSAR-derived displacements integrate all the events that occurred during the March-April eruption, they do not allow detailed analysis of the chronology of the early co-eruptive displacement at the Central Cone. Nevertheless, it is likely that the centripetal subsidence observed on the western flank of the Central Cone during the early coeruptive period affected the entire Central Cone, similarly as during the late co-eruptive period and the post-eruptive period, but that this subsidence was partly masked, on the early co-eruptive displacement, by the NS uplift due to the March 30 dyke.

Considering only the western flank of the Central Cone, the extension of the area of centripetal subsidence does not change significantly between the early co- and post-eruptive periods. This suggests that sources responsible for the deflation in the early co-eruptive period and in the post-eruptive period are possibly the same. 


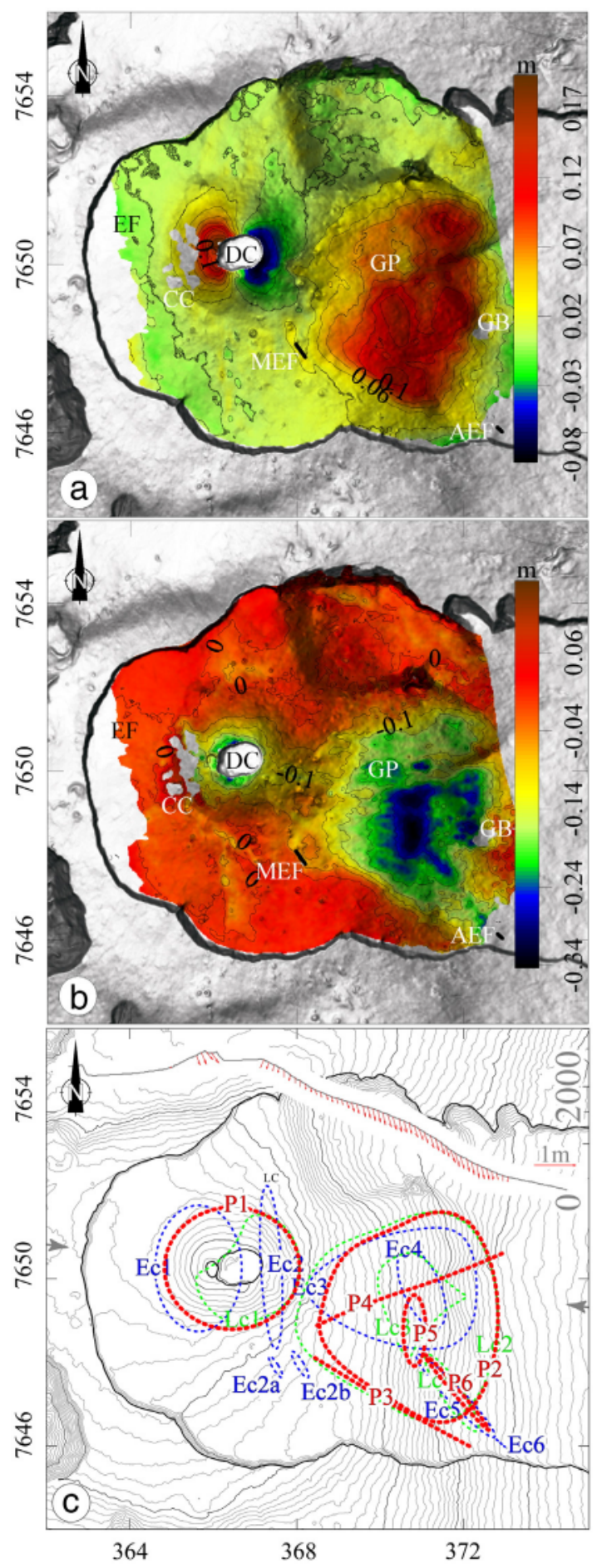

Fig. 6. One year post-eruptive displacements draped on the shaded DEM. a) EW component, contour level interval is $0.02 \mathrm{~m}$. b) Vertical component, contour level interval is $0.05 \mathrm{~m}$. c) Sketch map of the main post-eruptive displacement patterns (red dashed lines) referred to as P1 to P6 and superimposed onto the main early and late co-eruptive displacement patterns (blue and green dashed lines, respectively) for comparison. Grey arrows point to the extremities of the profile of the displacement vectors shown in the upper part of the figure. Thick bladk lines in a) and b) represent the location of eruptive fissures. AEF: April 2, 2007 eruptive fissure; MEF: March 30, 2007 eruptive fissure; CC: Central Cone; EF: Enclos Fouqué; GB: Grand Brûlé; GP: Grandes Pentes; LC: Langlois Cone. Coordinates are in km UTM (40 zone south). (For interpretation of the references to color in this figure legend, the reader is referred to the web version of this article.)

We provide some constraints on this source by carrying out inversion of the post-eruptive displacements (Augier, 2011). For simplicity, we assume an elastic, homogeneous and isotropic edifice, with a
Young's modulus of $5 \mathrm{GPa}$, and a Poisson's ratio of 0.25 (Cayol and Cornet, 1998). We use a 3-D Mixed Boundary Element Method (Cayol and Cornet, 1997), combined with a neighbourhood inversion method (Sambridge, 1999a) following the approach proposed by Fukushima et al. (2005). Although this approach does not allow investigation of the temporal evolution of inelastic displacements, it can provide a first order estimate of the source location as long as we restrict the inversion to the post-eruptive period, since post eruptive displacements at Central Cone are not affected by the NS dyke and the instantaneous effect of the crater collapse. We test a variety of source geometries including a vertical elliptical cylinder, an ellipsoid and a horizontal elliptical dislocation. We assume that the first geometry is a good proxy for the fractured, brecciated column of rock that extends from the floor of Dolomieu crater to the roof of the presumed main magma storage zone (Gailler et al., 2009). We consider the second and third geometries as good proxies for the magma storage zone or a hydrothermal system. Input data are the post-eruptive InSAR-derived displacements resampled using a quadtree partitioning method (Jónsson, 2002). For each source geometry, we solved for the best-fitting source parameters (describing the dimensions, orientations and location of the source and the pressure variation on its boundary). We then estimated confidence intervals on these parameters computing their posterior probability density function from the ensemble of forward models generated during the search (Sambridge, 1999b). Both source parameters and best fitting models are summarized in Online Resource 4. Ellipsoids and elliptical dislocations provide significantly better misfit values than the vertical elliptical cylinder. The most important feature highlighted by this preliminary modelling is that, whatever the geometry, a very shallow deformation source is required to explain the observed displacements (i.e. with source center depth between $1858 \mathrm{~m}$ and $2378 \mathrm{~m}$ above sea level). Because we assume the co-eruptive and post-eruptive displacement sources to be very close or the same, these conclusions may hold for the source of co-eruptive deflation as well.

\subsubsection{Post-eruptive subsidence decay}

In Fig. 7, we compare the post-eruptive displacement recorded at a summit GPS station (BONg, Fig. 1) with the InSAR-derived displacement calculated at the pixel nearest to the station. Both times series show a similar exponentially decreasing subsidence that continues for at least a year after the end of the March-April 2007 eruptions. A vanishing deflation of the main magma storage zone associated with the March-April 2007 eruptions could not explain this behaviour since the deflation source inferred by our numerical modelling is significantly shallower than the estimated depth of this storage zone (i.e. $460 \mathrm{~m}$ a.s.l., Peltier et al., 2009b). We think that a combination of two processes can more plausibly explain the post-eruptive exponential subsidence of the Central Cone. The first

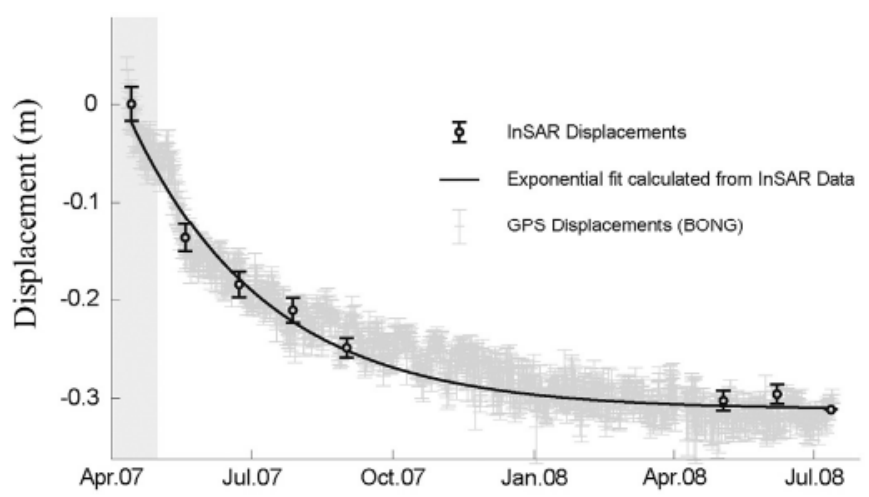

Fig. 7. Comparison of the measurements recorded at summit GPS station BONg (see Fig 1 for location), projected in the LOS of ASAR ascending swath 7 (in grey) with the InSAR-derived displacements (ascending swath 7) calculated at the nearest pixel (in black). Exponential regression on the InSAR data (black line) gives a relaxation time of 61 days. The grey box indicates the period of April 2007 eruption. 
process consists in the elasto-visco-plastic deformation of the Central Cone in response to the cavity created by the Dolomieu collapse. Although most creep should occur in the portion of the Central Cone between the summit and the floor of the collapsed column (at $~ 380 \mathrm{~m}$ below the summit), the strongly brecciated and cohesion-less rock column may also contribute to the deformation of the upper edifice by closing the voids created during the column collapse. The second process could be the sudden depressurization of a hydrothermal system within the Central Cone, causing a large deflation at the time of the Dolomieu collapse followed by an exponential decrease in the months after the eruption. Several observations support the presence of a shallow hydrothermal system beneath the Dolomieu crater and its depressurization during the Dolomieu caldera collapse. These observations include the large positive selfpotential anomaly centered on the Central Cone (Malengreau et al., 1994; Lénat et al., 2000; Lénat, 2007; Barde Cabusson et al., 2012), the seismicity beneath the summit craters, attributed to hydrofracturing (Lénat et al., 2012), the series of ash plumes emissions, possibly of phreatic origin, following the April 5 to April 9 caldera collapse (Staudacher et al., 2009; Michon et al., 2013), the $\mathrm{SO}_{2}$ plume rising from the summit at about the same period (Gouhier and Coppola, 2011), and finally the hightemperature (up to $200^{\circ} \mathrm{C}$ ) steam plumes emanating from the new crater in the days following the collapse (Urai et al., 2007).

We therefore propose a conceptual model that explains all these observations as well as the displacements affecting the Central Cone before, during, and after the 2007 eruption (Fig. 8). An active hydrothermal system occupies the highly porous, cohesion-less, rock column between the floor of Dolomieu crater and the roof of the magma storage zone (Lénat et al., 2012). The hydrothermal system may also extend laterally into the Central Cone, outside of the cohesion less rock column, in scoriaceous levels that intercalate with the more massive lava units (Barde Cabusson et al., 2012). Before the August 2006 eruption, this hydrothermal system had a free surface at the top. The lava flow that filled up the Dolomieu crater from August to December 2006 (about $20 \times 10^{6} \mathrm{~m}^{3}$, Peltier et al., 2009a) temporary sealed the upper boundary of the hydrothermal system. Subsequent heating of the hydrothermal fluids by the underlying magma reservoir induced a progressive pressurization of this shallow hydrothermal system and resulted in a short scale inflation of the Central Cone. This inflation probably contributed to the continuous inflation recorded by the GPS stations in the months preceding the March-April 2007 eruptions and previously attributed to the recharge of the main magma storage zone (Peltier et al., 2009b). When the Dolomieu collapsed, the hydrothermal system was suddenly depressurized (Fig. 8b),

a) Pressurization of the hydrothermal system in the months preceding the April 2007 eruption

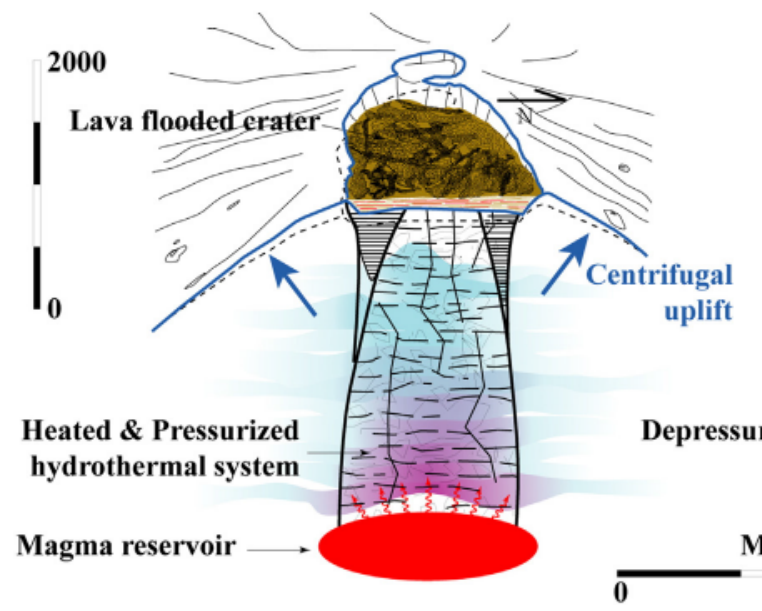

generating firstly phreatic blasts, then $\mathrm{SO}_{2}$ and steam emissions. As a consequence of the hydrothermal system depressurization, the Central Cone experienced a strong initial centripetal subsidence which then decreased exponentially because of the poroelastic relaxation and/or the creep of the Central Cone.

The idea that a hydrothermal system could have acted as a deformation source within the Piton de la Fournaise during the March-April 2007 leads us to reconsider the interpretation of the displacements recorded during inter-eruptive periods at the Central Cone. These intereruptive displacements are mentioned by Peltier et al. (2009a), as one of the pieces of evidence for the major changes which occurred since 2000 in the shallow plumbing system. They consist of long-term (1 to 5 month) pre-eruptive inflation and generally shorter (some weeks) post-eruptive deflation. They have been interpreted as related to the progressive infilling or emptying of the main magma storage zone located between 0 and $1000 \mathrm{~m}$ a.s.l. below the Central Cone (Peltier et al., 2008,2009 a). However such an interpretation is problematic since the inter-eruptive displacements, imaged with InSAR data, are characterized by a relatively short scale signal that does not extend beyond the Central Cone area (Tinard, 2007). This characteristic is not compatible with a deep source (i.e. a source between 0 and $1000 \mathrm{~m}$ a.s.l.) which would produce a larger scale displacement pattern. An alternative explanation could be that the pre-eruptive inflation is related to the pressurization of a shallow hydrothermal system in response to an increase in the heat and fluid flux originating from a magmatic source located somewhere below. The magmatic source itself will not necessarily produce detectable ground surface displacement if it is too deep (Fukushima et al., 2005). After the eruption, the hydrothermal system pressure may have dropped gradually, either due to partial escape of pressurized fluids following the disruption of the hydrothermal system during dyke injection, or simply because of the disappearance of the heat source. In this model, the hydrothermal system could be considered as a poro-elastic buffer that partially delays and extends through time the geodetic manifestation of a deeper magmatic source. This kind of behaviour has been reported at Campi Flegrei and Long Valley (Hurwitz et al., 2007).

\subsection{Displacement of the Grandes Pentes}

\subsubsection{A detachment responsible for the co-eruptive displacement}

Three categories of processes have been proposed to cause flank displacements on basaltic volcanoes (see McGuire, 1996 for a review). In

\section{b) Depressurization of the hydrothermal system during and after the April 2007 eruption}

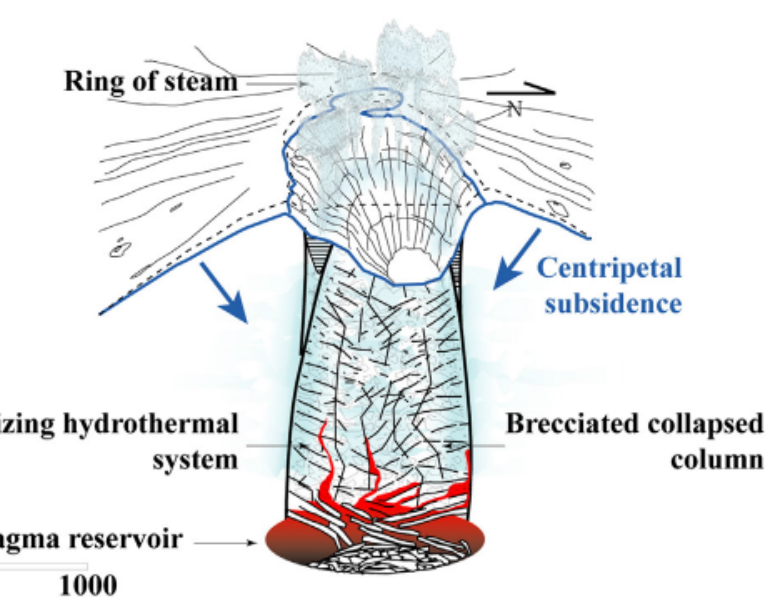

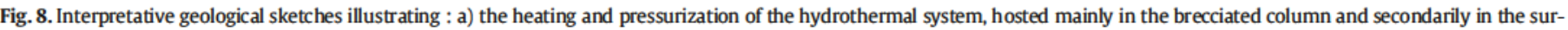

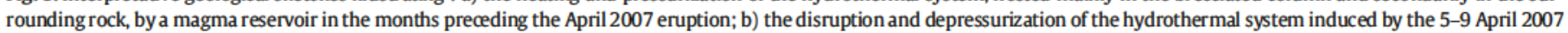
collapse of Dolomieu crater. 
the first category, gravity is the only driving force that leads to spreading of the edifice under its own weight. In the second category, flank displacement is induced by the combined effects of gravity and forceful magma intrusions (Delaney et al., 1990) or olivine cumulates creep (Clague and Denlinger, 1994) in deep dike-like rift zones (Dieterich, 1988; Iverson, 1995). In these models, magmatic stresses, gravity induced stresses and fault displacements are coupled (Dieterich, 1988; Iverson, 1995). In the third category, flank displacement is triggered by hydrothermal pressurization (e.g. Reid, 2004). In these three categories, spreading results in the development of a slip surface which may be a décollement (i.e. a thrust along a lithological discontinuity) or a detachment (i.e. a low-angle normal fault).

Our InSAR-derived displacements show that Piton de la Fournaise volcano underwent an unusually large deformation during the March-April 2007 eruptions, dominated by a widespread seaward sliding sector of the Grandes Pentes. These results suggest, and numerical modelling confirms (Got et al., 2013; Chaput et al., 2014; Cayol et al., in press), that a slip surface does exist underneath the Eastern Flank of Piton de la Fournaise, as proposed long ago (e.g. Duffield et al., 1982). In addition, our results show that this slip surface has been activated during an eruption, an event which had not been previously observed for this volcano. Because the large scale, vertical, early co-eruptive displacement of the Grande Pentes is subsidence, the slip surface must be a normal fault with an eastward (seaward) dip. Given the average plunge of the displacement vectors $\left(15^{\circ}\right.$, Fig. $\left.4 \mathrm{c}\right)$, it is also likely that this normal fault has a low dip angle roughly parallel to the local average slope. We therefore propose that the structure responsible for the co-eruptive displacement of the Grandes Pentes is a detachment.

\subsubsection{Did the March 30 dyke intrusion trigger the detachment slip?}

This question may be answered by establishing the chronological succession of deformations from the March 30 dyke to the April 2 eruption and the initiation of the slip motion. From the comparison of the early and the late co-eruptive InSAR displacement, it appears that most slip occurred during the early phase of the eruption (i.e. before April 6). Unfortunately, these data do not allow a more accurate chronological analysis of the displacements since they integrate all the events between March 30 and April 5-6.

Observations of continuous seismic velocity changes, measured using cross-correlations of ambient seismic noise, provide additional temporal constraints (Clarke et al., 2013). A strong seismic velocity reduction episode, affecting the Eastern Flank of Piton de la Fournaise, is observed starting on March 30. Clarke et al. (2013) explained this episode as a consequence of the widespread eastward movement of the Eastern Flank, thus confirming the early nature of this displacement.

Temporal analysis of GPS data made by Got et al. (2013) provides additional information on the chronology of displacements (Fig. 2b in Got et al., 2013). On March 30, at 16:25, the easternmost GPS station, FERg, started to record an uplift exceeding the background noise (see stations locations in Fig. 1). Then, at 16:30, the summit GPS stations recorded an inflation of the Central Cone, while FERg started to record an eastward displacement in addition to the upward displacement. At 16:38 the summit stations detected a contraction of the Central Cone while the horizontal displacement became reoriented toward the NE at FERg. From this time on, upward and NE displacements were also recorded at FJSg and upward and SW displacements at FORg. Got et al. (2013) interpreted this sequence of displacements as a first stage of magma intrusion occurring below FERg GPS station in the form of a subhorizontal pressurized structure (i.e. a sill). Then the March 30 dyke intrusion, revealed by the displacements recorded at FJSg and FORg, occurred during a second stage. This interpretation is also supported by the return of FJSg and FORg displacements to a level of background noise at the onset of the March 30 eruption, while the FERg eastward displacement continued for at least two days with an exponentially decreasing magnitude (Fig. 9). It is reasonable to assume that this eastward displacement recorded at the FERg station is related to slip of the Grandes Pentes.
Thus, eastward displacement of the Grandes Pentes preceded the March 30 dyke intrusion by $8 \mathrm{~min}$. It is therefore likely that the detachment slip, similarly as indicated by the stress models of Chaput et al. (2014), reduced the minimum principal stress close to the summit, allowing the injection of the March 30 dyke. If so, the March 30 dyke would merely be a consequence of the onset of sliding rather than a trigger.

\subsubsection{An intrusion within the central Eastern Flank}

The $\sim \mathrm{N} 170^{\circ} \mathrm{E}$ trending uplift, superimposed on the detachment slip, revealed by early co-eruptive InSAR data (Ec4 in Fig. 4c), suggests an inflation source within the central Eastern Flank. The late co-eruptive displacement shows a subsidence at the location of this early co-eruptive uplift (Lc3 in Fig. 5c). The displacement pattern observed at this location on the descending swath/track 5/048 interferogram (Fig. 3d) demonstrates that this subsidence was already active on April 6, after the 5-6 April collapse. Thus, the $\mathrm{N} 170^{\circ} \mathrm{E}$ inflation must have been restricted to the beginning of the eruption (as was the uplift at the FERg GPS station), and was followed by deflation along the same $\mathrm{N} 170^{\circ} \mathrm{E}$ axis. It is possible that this $\mathrm{N} 170^{\circ} \mathrm{E}$ axis represents a migration of the inflation from the FERg station toward the east, although the absence of continuous GPS stations in the Grandes Pentes does not allow this hypothesis to be confirmed. From the migration of the eruptive vents, it is likely that the propagation of magma toward the April 2 fissure interrupted the supply of magma at the March 30 fissure. Moreover, the InSAR data show that the two eruptive fissures cannot be related to a single $\mathrm{N} 120^{\circ} \mathrm{E}$ intrusion as suggested by Peltier et al. (2009b). This leads us to propose that another intrusion propagated from beneath the Central Cone independently of the March 30 NS dyke. While propagating toward the east, this intrusion uplifted the volcano at the FERg station, before inflating the Grande Pentes along the $\mathrm{N} 170^{\circ} \mathrm{E}$ axis, and eventually opening up the April 2 fissure (Fig. 10). The N125-135 ${ }^{\circ} \mathrm{E}$ subsiding axis, observed at the south-eastern base of the Grandes Pentes, on both co- and posteruptive displacements (features Ec5, Lc4 and P6 in Figs. 4c, 5c and 6c respectively), would then mark the final path of the magma toward the April 2 eruptive site. The subsequent emission of lava through the April 2 eruptive fissure resulted in the progressive withdrawal of magma accumulated beneath the Grandes Pentes, causing the subsidence observed on the late co-eruptive and post-eruptive displacements. A temporary magma accumulation within the Grandes Pentes between March 30 and April 2 is also supported by the anomalous depletion in $\mathrm{Li}, \mathrm{Cu}$ and $\mathrm{Tl}$ observed in the first lavas erupted on April 2 (Vlastélic et al., 2013), which suggests that the April 2007 magma was stored in a shallow reservoir ( $590 \mathrm{~m}$ above sea level) for some hours to some days allowing extraction of these elements by a rapidly exsolving $\mathrm{H}_{2} \mathrm{O}$-rich phase (Vlastélic et al., 2013).

\subsubsection{Sill injection promoting detachment slip}

Assuming that the Eastern Flank intrusion is planar and propagating from the magma storage zone located below the Central Cone, between 0 and $1000 \mathrm{~m}$ a.s.l., our interpretation of InSAR co-eruptive displacements imposes some geometrical constraints on the strike and dip of this intrusion surface. Firstly, the intrusion should have a $\mathrm{N} 170^{\circ} \mathrm{E}$ strike underneath the Grandes Pentes in order to yield the observed uplift axis. Secondly, the large ratio of horizontal over vertical displacement is indicative of a shallow subhorizontal fracture (Fig. 10 of Cayol et al., in press). Thirdly, the intrusion likely propagated from underneath the cone (where the seismicity is located and the magma storage zone inferred) toward the east. Fourthly, the intrusion should have a suitable geometry underneath the Grandes Pentes to promote the slip of a low-angle normal fault. Moreover, GPS data indicate that the March 30 uplift at the FERg GPS station, assumed to be caused by the planar intrusion, preceded eastward displacement of the Grandes Pentes by $5 \mathrm{~min}$. Based on these geometrical and temporal constraints, we suggest that this intrusion could be a sill for the main part of its course. During its propagation to the surface the intrusion may have encountered 


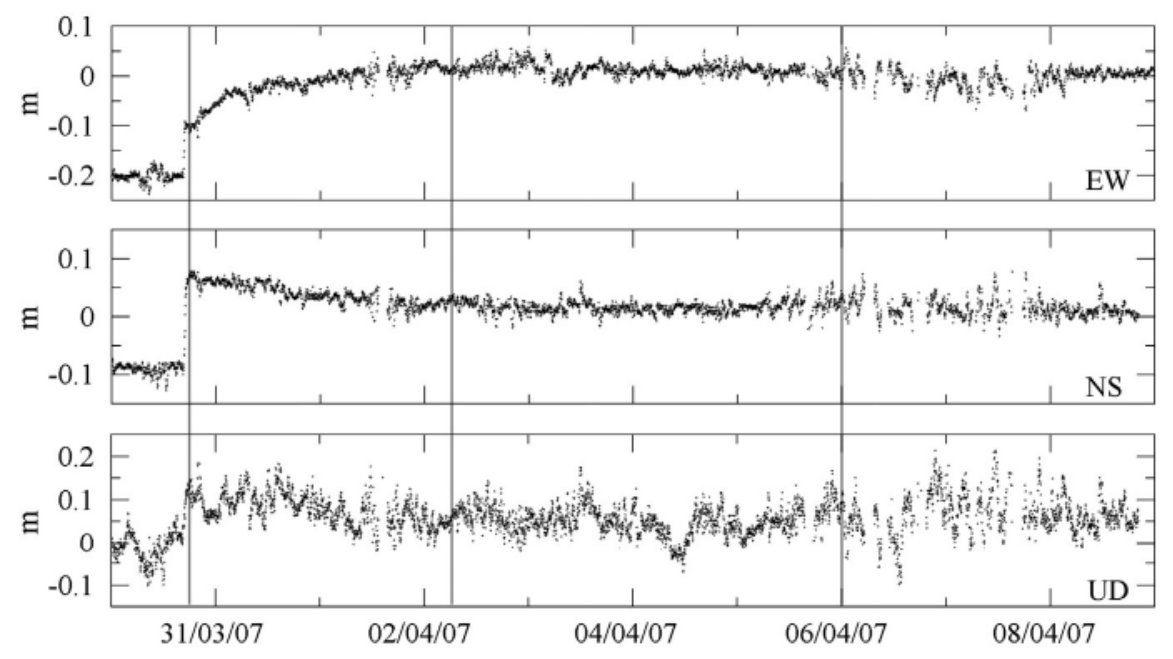

Fig.9. Horizontal and vertical displacements recorded at the OVPFGPS station FER (see Fig. 1 for location of the station) between March 30,2007 and April 8,2007. Vertical lines represent the main eruptive episodes (March 30 eruption, April 2 eruption and April 6 collapse).

a) Before March 30, 16:25, first intrusion

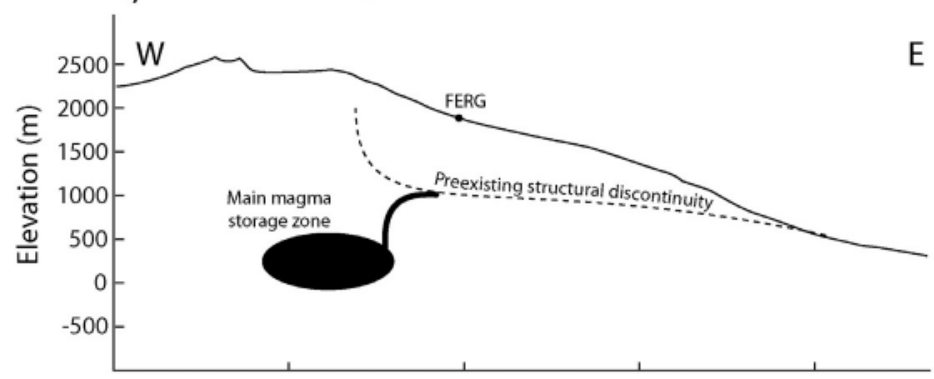

C) March 30, 16:30, intrusion within the Grander Pontes, detachment slip

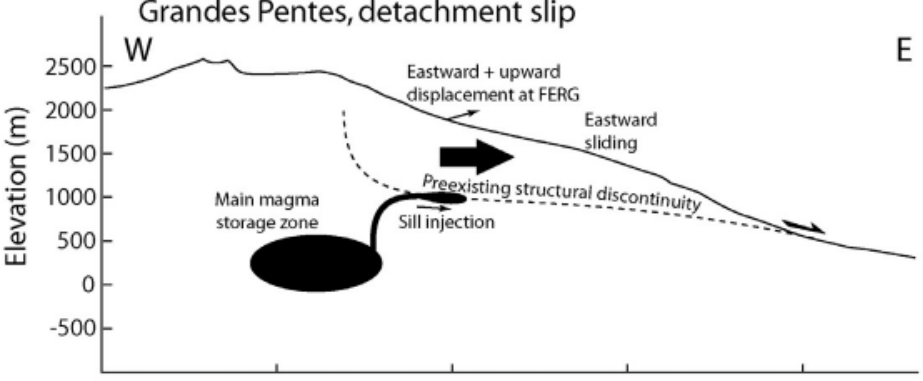

e) March 31 - April 2, sill arrest and inflation

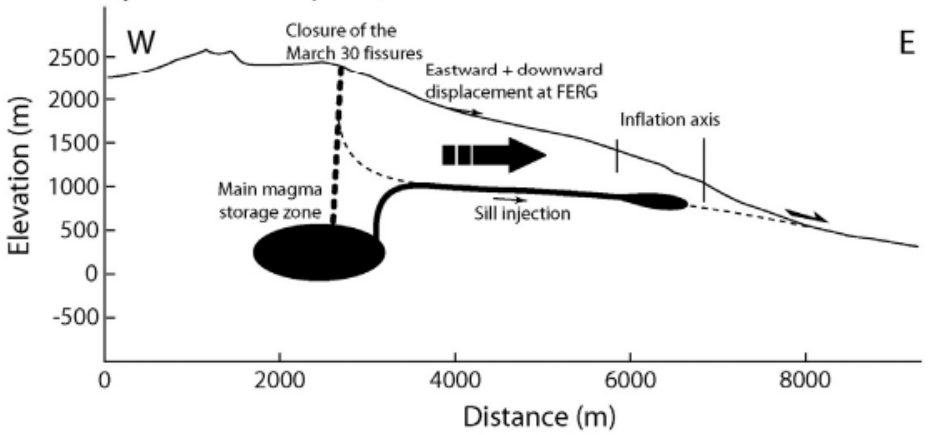

b) March 30,16:25, the intrusion propagates as a sill in a preexisting discontinuity

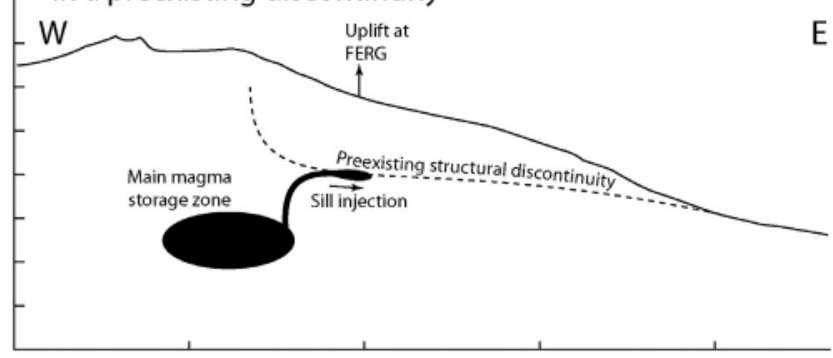

d) March 30, 16:38 - 19:00, Dyke intrusion

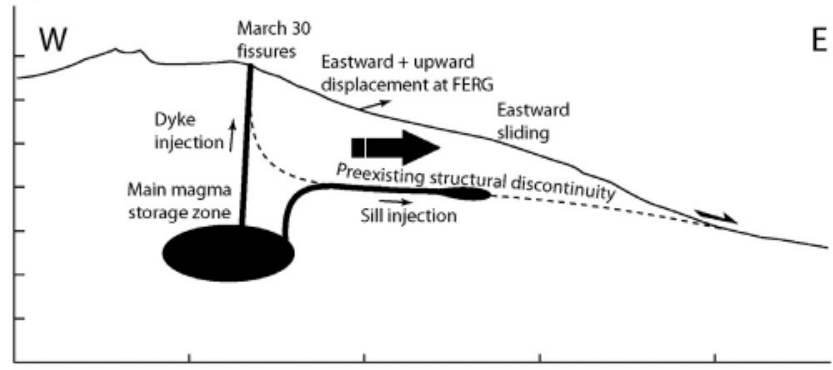

f) April 2, Sill reaches the surface, decay of the detachment slip

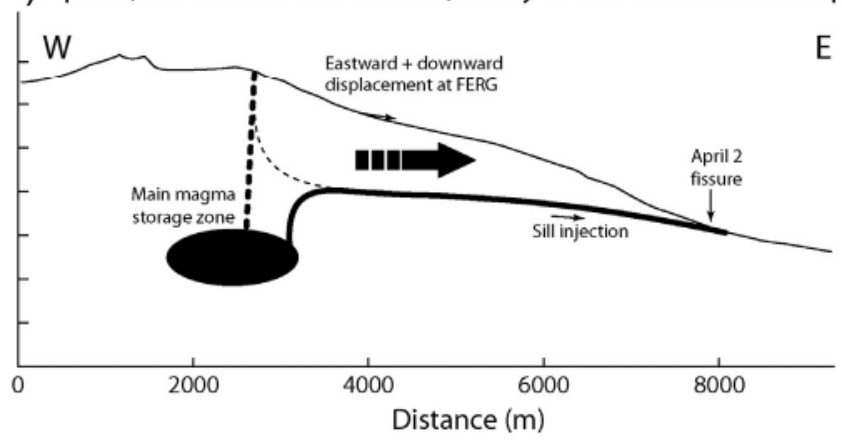

Fig. 10. Conceptual cross-sectional sketch illustrating the different steps of the April 2007 events in the Grandee Pentes. a) Before March 30, 16:25, a first intrusion, initiated from the eastern wall of the main magma storage zone and propagated, as a dyke, to the surface. b) During its propagation the intrusion encountered a preexisting structural discontinuity, exploited it to pursue its propagation as a sill, inducing the FER GPS station uplift at 16:25. c) On March 30, at 16:30 the sill activated the structural discontinuity as a detachment surfaced) On March 30, at 16:38, change in the host rock stress field, resulting from slip of the detachment, allowed a new intrusion to propagate as a dyke from the upper part of the main magma storage.e) Between March 31 and April 2, supply of magma at the March 30 fissure is interrupted and the sill propagation is arrested, inducing magma accumulation within the Grandes Pentes and inflation at the surface. f) The sill resumes its propagation within the Eastern Flank and reached the surface. The detachment slip starts to decay. 
some pre-existing structural discontinuity, exploited it to pursue its propagation and then activated it as a detachment plane (Fig. 10).

This model is supported by observations made at Piton des Neiges, the extinct volcano of La Réunion Island, where Famin and Michon (2010) reported the existence of a kilometre-scale detachment, with a low-angle dip $\left(\sim 15^{\circ}\right)$ toward the sea. About $50-70$ sills of oceanite magmas were repeatedly injected into this detachment. Based on these observations, Famin and Michon (2010) proposed a model in which sill intrusions were guided by the preexisting detachment, rather than emplaced perpendicular to the minimum principal stress. For this reason, host rocks induce shear stress on the intrusion, which then acts as a trigger to fault slip (Chaput et al., 2014; Cayol et al., in press). The detachment of Piton des Neiges could represent a frozen analogue of the process of co-eruptive flank displacement recorded at Piton de la Fournaise in 2007. It is interesting to note that the oceanite composition of magmas emitted at the April 2 vent, and more generally at the distal vents of Piton de la Fournaise, is different from that of the March 30 dyke, but similar to that of sills in the Piton des Neiges detachment (Famin and Michon, 2010). Due to their high density, oceanite magmas ( $d \geq 3.1$ ) are associated with larger overpressures and are more able to propagate along low-dipping fissures (i.e. sills) than aphyric basalts ( $d \leq 2.9$ ). In addition, it has been proposed that intrusions composed of oceanite magmas stem from the deeper parts of the magma reservoir enriched in cumulative olivine (Peltier et al., 2008; Welsch et al., 2009). Another argument in favour of a sill injection triggering detachment slip comes from theoretical numerical models of intrusions into coneshaped edifices, showing that the surface displacements obtained from a sill intrusion into a fault result in a sector collapse with an uplift axis above the tip of the sill (Chaput et al., 2014; Cayol et al., in press), as observed in our InSAR co-eruptive displacement maps. If so, the tip of the sill would have been located beneath the uplifted axis in the Grandes Pentes before the April 2 eruption. To conclude, early coeruptive displacements of the Eastern Flank, recorded by InSAR data during the March-April 2007 eruptions, are thus more compatible with a scenario of "sill-induced spreading" (i.e. flank collapse triggered by sill injection in a detachment) rather than "rift-induced spreading" (i.e. flank displacement pushed by a dyke).

\subsubsection{Post-eruptive subsidence of the sliding sector}

One of the most significant results provided by the analysis of the post-eruptive displacements is the exponentially decrease of the downslope motion of the Grandes Pentes for at least one year after the end of the March-April 2007 eruptions, with an exponentially decreasing amplitude. A similar time-dependent behaviour has been described previously for the eastern flank of Mount Etna which is affected by intermittent ESE seaward sliding related to magma intrusions (e.g. Froger et al., 2001; Rust et al., 2005; Bonforte and Puglisi, 2006; Palano et al., 2009). To explain the time-dependent deformation observed after the onset of the 2002-03 Mount Etna eruption, Palano et al. (2009) invoked two possible mechanisms: viscoelastic relaxation, or after-slip relaxation. At Piton de la Fournaise, the lack of noticeable seismicity in the Grandes Pentes in the months following the 2007 eruption favors viscoelastic relaxation. However the mechanism responsible for this viscoelastic behaviour is still unclear. It cannot be attributed to a post-eruptive slip on the detachment, because the post-eruptive displacement vectors in the Grandes Pentes have a much higher dip $\left(65-75^{\circ}\right.$, displacement profile in Fig. $\left.6 \mathrm{c}\right)$ than the early co-eruptive displacement vectors $\left(15^{\circ}\right.$, displacement profile in Fig. 4c). Since the maximum post-eruptive subsidence (P5 in Fig. 6c) coincides relatively well with the location of the early co-eruptive $\mathrm{N} 170^{\circ} \mathrm{E}$ uplift in the Grandes Pentes (Ec4 in Fig. 4c) and with the N125-130 $\mathrm{E}$ co-eruptive subsiding axis at the SE base of the Grandes Pentes (EC5 in Fig. 4c), both interpreted as being due to magma migration, it is tempting to attribute the post-eruptive subsidence to a thermo-mechanical evolution of the intrusion in the Grandes Pentes. However, this interpretation is unlikely as (i) the area of post-eruptive displacement is larger than the area of co-eruptive displacement, and (ii) a simple computation (taking only conductive heat transfer into account) shows that an unrealistic thickness of the cooling intrusion would be required to explain the post-eruptive subsidence.

We note that post-eruptive displacements in the Grandes Pentes are delimited by sharp features (P3-P4 in Fig. 6c). The fact that these structures are not visible on the early co-eruptive displacement maps suggests that they may have appeared at the end of the activation stage of the slip event. One of these sharp features, the central N65-70 $\mathrm{E}$ lineament (P4 in Fig. 6c), coincides with a previously recognized normal fault (Michon and Saint-Ange, 2008). Given the high dip of the displacement vectors $\left(65-75^{\circ}\right)$, it is possible that the other sharp feature also corresponds to a normal fault. These normal faults could have been activated in the post-eruptive period by the EW extensional stress field resulting from the early co-eruptive Grandes Pentes displacement. Creep on these normal faults would control the response of the edifice to the change in stress field imposed by the co-eruptive period.

\section{Conclusions}

We measured the displacements that occurred during and after the March-April 2007 eruptions at Piton de la Fournaise using both ASAR (C-band) and PALSAR (L-band) InSAR data. Joint use of the two radar wavelengths has been shown to be a valuable way of characterizing the displacement. Indeed, PALSAR ascending data allow the computation and removal of the large scale component of displacements from the ASAR ascending data, reducing fringe aliasing in the ASAR data, and thus improving phase unwrapping. This demonstrates the feasibility of partial signal recovery in incoherent interferograms when the coherence loss is due to large strain gradients inducing fringe aliasing. It also illustrates the interest of combining data from different InSAR sensors to improve characterization of ground displacements. In addition, our work illustrates the great advantage of simultaneous multi-swaths data, acquired both in ascending and descending passes, to properly determine the EW and vertical components of displacement and better understand their origins.

The early co-eruptive displacement pattern results from the superimposition of multiple processes related to the March 30 eruption, the April 2 eruption, and the April 5-9 collapse of Dolomieu crater. The post-eruptive displacements show evidence of time-dependent processes acting both at the Central Cone and in the Grandes Pentes.

An inversion of the post eruptive displacement recorded at the Central Cone showed that the source of deflation is very shallow. Therefore, we propose that the observed displacements are related to the decompression of a pressurized hydrothermal system during the Dolomieu collapse. In the last decade, a growing corpus of evidence has allowed volcano deformation to be attributed to hydrothermal systems at widespread volcanoes (Gottsmann et al., 2006; Rinaldi et al., 2010; Fournier and Chardot, 2012). At Piton de la Fournaise, the role of the hydrothermal system had been neglected for a long time before the model proposed recently by Lénat et al. (2012) where the hydrothermal system is considered as a possible eruption trigger. Our results lead us to propose that the hydrothermal system may also be responsible for the short-wavelength displacements recorded at the Central Cone during inter-eruptive periods. Hydrothermal displacement sources are probably more frequent than previously supposed and should be carefully considered on all volcanoes where there is evidence of an active hydrothermal system. This would require a particular care to be taken in the design of geodetic networks in order to be able to discriminate deep magmatic sources from shallow hydrothermal sources.

The displacement measured in the Grandes Pentes is the first direct evidence of a large active seaward motion affecting the Eastern Flank of Piton de la Fournaise. This evidence is a strong argument in favour of the previously proposed interpretations of the eastern part of the Enclos Fouqué-Grand Brûlé structure resulting from successive eastward flank destabilization (Lénat et al., 1990; Labazuy, 1996; Lénat et al., 2001 ). Here we propose that the origin of this displacement is related 
to a sill intrusion within the Grandes Pentes. While propagating to the surface the intrusion may have encountered a pre-existing structural discontinuity and activated it as a detachment fault. This scenario provides an explanation for magma transfer from the main magma storage zone, beneath the Central Cone to the April 2 eruption site. It is supported by the displacement measured early on March 30 at the easternmost GPS station (FERg, Got et al., 2013). It is also in agreement with the field observations made at Piton des Neiges, the older and deeply eroded analogue of Piton de la Fournaise, which led Famin and Michon (2010) and Chaput et al. (2014) to propose a possible positive feedback between flank destabilization and sill injection.

Our interpretations of the Central Cone and the Grandes Pentes displacements are essentially based on a qualitative analysis. They provide a conceptual framework that now needs to be explored further by means of numerical modelling. In particular, the thermo-mechanical interaction between a deep-seated magmatic source and a shallower hydrothermal system within the Central Cone should be investigated, as well as the effect of an intrusion into a pre-existing structural discontinuity beneath the Grandes Pentes. In the latter case, numerical modelling, similarly as those developed by Chaput et al. (2014) or Cayol et al. (in press) could help to evaluate the possibility of inducing a large catastrophic flank destabilization by recurrent sill intrusions. The potential hazard posed by such large flank destabilization emphasizes the need for continuous monitoring of the Grandes Pentes. At the time of the March-April 2007 eruption, OVPF geodetic and seismic monitoring network did not extend to the Grandes Pentes, and, without InSAR, the Grandes Pentes displacement would have gone unnoticed. Despite the fact that, since this eruption, OVPF monitoring networks have been extended to the Grandes Pentes, this clearly illustrates the benefit of using satellite remote sensing data to monitor remote or dangerous areas on volcanoes.

\section{Acknowledgements}

The authors would like to especially thank Fran Van Wyk de Vries for early reviews of this manuscript. We thank also the JAXA and the European Space Agency for providing the ALOS-PALSAR data through the ALOS-ADEN project \#3622 and the European Space Agency for providing the ASAR data through the AO-ENVISAT project \#746. The PALSAR and ASAR interferograms were produced with the Diapason Software. The interpretations we present in this paper owe much to the geophysical and field observations collected during the March-April 2007 eruption by the staff of the Volcanological Observatory and by our colleagues of La Réunion University. Discussions with P. Bachèlery, A. Finizola, P. Labazuy, Ph. Mairine, A. Di Muro, A. Peltier, T. Staudacher and $\mathrm{N}$. Villeneuve greatly helped us to develop these interpretations. Comments made by two anonymous reviewer help us to improve the manuscript.

\section{Appendix A. Supplementary data}

Supplementary data to this article can be found online at http://dx. doi.org/10.1016/j.jvolgeores.2015.02.014.

\section{References}

Augier, A, 2011. Etude de l'éruption d'avril 2007 du Piton de la Fournaise (île de la Réunion) à partir de données d'interférométrie RADAR et GPS, développement et application de procédure de modélisation. (Ph.D. thesis). Université Blaise Pascal, Clermont-Ferrand, France.

Augier, A., Froger, J.-L, Cayol, V, 2008. The April 2007 eruption at Piton de la Fournaise, Réunion Island, imaged with ENVISAT-ASAR and ALOS-PALSAR data. USEReST Workshop, November 11-14, Napoli, Italy.

Bachèlery, P., 1995. Quelques réflexions à propos de concepts récents sur la structure du Piton de la Fournaise, Réunion. Rapport Quadriennal 1991-1994. Comité National Français de Géodésie et de Géophysique, Paris
Bachèlery, P., Mairine, P., 1990. Evolution volcano-structurale du Piton de la Fournaise depuis $0.53 \mathrm{Ma}$. In: Lenat, J.-F. (Ed.), Le volcanisme de la Reunion. Monographie, pp. 213-242.

Bachèlery, P., Saint-Ange, F., Villeneuve, N., Savoye, B, Normand, A., Le Drezen, E., Barrre, A., Quod, J.-P., Deplus, C, 2010. Huge lava flow into the sea and caldera collapse, April 2007, Piton de la Fournaise. IAVCEI Third Workshop on Collapse Calderas, La Réunion, pp. 73-74.

Barde Cabusson, S., Finizola A, Peltier, A, Chaput, M., Taquet, N., Dumont, S., Duputel, Z Guy, A., Mathieu, L, Saumet, L., Sorbadère, F, Vieille, M., 2012. Structural control of collapse events inferred by self-potential mapping on the Piton de la Fournaise volcano (La Réunion Island). J. Volcanol. Geotherm. Res. 209-210, 9-18.

Bato, M.G., Froger, J.-L, Harris, A.J.L., Villeneuve, N, Souriot, T., 2013. Characterizing the October 2010 lava flow of Piton de la Fournaise using X-Band InSAR data. IEEE International Geoscience and Remote Sensing Symposium, July 21-26, Melbourne, Australia.

Bonforte, A., Puglisi, G, 2006. Dynamics of the Eastern Flank of Mt. Etna volcano (Italy) investigated by a dense GPS network J. Volcanol. Geotherm. Res. 153, 357-369.

Cayol, V., Cornet, F.H., 1997. 3D mixed boundary elements for elastostatic deformation fields analysis. Int. J. Rock Mech. Min. Sci. Geomech. Abstr. 34, 275-287.

Cayol, V., Cornet, F.H., 1998. Effect of topography on the interpretation of the deformation field of prominent volcanoes - application to Etna. Geophys. Res. Lett. 25, 1979-1982.

Cayol, V, Catry, T., Michon, L, Chaput, M, Famin, V., Bodart, O., Froger, J.-L., Romagnoli, C, 2014. Sheared sheet intrusions as mechanism for lateral flank displacement on basaltic volcanoes: Applications to Réunion Island volcanoes. J. Geophys. Res. Solid Earth 119 http://dx.doi.org/10.1002/2014JB011139 (in press).

Chaput, M, Pinel, V., Famin, V., Michon, L., Froger, J.-L., 2014. Cointrusive shear displacement by sill intrusion in a detachment: a numerical approach. Geophys. Res. Lett. http://dx.doi.org/10.1002/ 2013GL058813.

Chen, C.W., Zebker, H.A., 2002. Phase unwrapping for large SAR interferograms: statistical segmentation and generalized network models. IEEE Trans. Geosci. Remote Sens. 40, 1709-1719.

Chevallier, L., Bachelery, P., 1981. Evolution structurale du volcan actif du Piton de la Fournaise, Ile de la Réunion - Océan Indien occidental. Bull. Volcanol. 44, 723-741.

Clague, D.A., Denlinger, R.P., 1994. Role of olivine cumulates in destabilizing the flanks of 1075 Hawaiian volcanoes. Bull. Volcanol. 56, 425-434. http://dx.doi.org/10.1007/ BF00302824.

Clarke, D., Brenguier, F., Froger, J.-L., Shapiro, N.M., Peltier, A., Staudacher, T., 2013. Timing of a large volcanic flank movement at Piton de la Fournaise volcano using noise-based seismic monitoring and ground deformation measurements. GII 195, 1132-1140.

CNES, 1996. Philosophie et mode d'emploi de la chaîne logicielle interférométrique. DIAPASON, Toulouse, France.

Delaney, P.T., Fiske, R.S., Miklius, A., Okamura, A.T., Sako, M.K., 1990. Deep magma body beneath the summit and rift zones of Kilauea Volcano, Hawaii. Science 247, 1311-1316

Di Muro, A., Métrich, N., Vergani, D., Rosi, M., Armienti, P., Fougereox, T., Deloule, E., Arienzo, I., Civetta, L, 2014. The shallow plumbing system of Piton de la Fournaise volcano (La Réunion Island, Indian Ocean) revealed by the major 2007 caldera forming eruption. J. Petrol. 55, 1287-1315.

Dieterich, J.H., 1988. Growth and persistence of Hawaiian volcanic rift zones. J. Geophys. Res. 93, 4258-4270.

Duffield, W.A., Stieljes, L., Varet, J, 1982. Huge landslide blocks in the growth of Piton de la Fournaise, La Réunion, and Kilauea Volcano, Hawaii. J. Volcanol. Geotherm. Res. 12, 147-160.

Dzurisin, D., 2007. Volcano Deformation - Geodetic Monitoring Techniques. Springer, Berlin (441 pp.).

Famin, V, Michon, L, 2010. Volcano destabilization by magma injections in a detachment. Geology 38, 219-222.

Fialko, Y., Pearse, J., 2012. Sombrero uplift above the Altiplano-Puna Magma Body: evidence of a ballooning mid-crustal diapir. Science 338, 250-252.

Fontaine, F.R., Roult, G., Michon, L., Barruol, G., Di Muro, A., 2014. The 2007 eruptions and caldera collapse of the Piton de la Fournaise volcano (La Réunion Island) from tilt analysis at a single very broadband seismic station. Geophys. Res. Lett. http://dx.doi.org/10.1002/2014GL059691.

Fournier, N., Chardot, L, 2012. Understanding volcano hydrothermal unrest from geodetic observations: insights from numerical modeling and application to White Island volcano, New Zealand. J. Geophys. Res. http://dx.doi.org/10.1029/2012JB009469.

Froger, J.-L., Merle, O., Briole, P., 2001. Active spreading and regional extension of Mount Etna imaged by SAR interferometry. Earth Planet. Sci. Lett. 187, 245-258.

Froger, J.-L., Fukushima, Y., Briole, P., Staudacher, Th., Souriot, Th, Villeneuve, N., 2004. The deformation field of the August 2003 eruption at Piton de la Fournaise, Reunion Island, mapped by ASAR interferometry. Geophys. Res. Lett. http://dx.doi.org/10. 1029/2004GLO20479.

Froger, J.-L, Remy, D, Bonvalot, S, Legrand, D., 2007. Two scales of inflation at LastarriaCordon del Azufre volcanic complex, central Andes, revealed from ASAR-ENVSAT interferometric data. Earth Planet. Sci. Lett. http://dx.doi.org/10.1016/j.epsl.2006.12.012.

Froger, J.-L., Bato, M.G., Villeneuve, N., Souriot, T., Rabaute, T., Durand, P., Cayol, V., Di Muro, A., Staudacher, T., Fruneau, B., Tinel, C, 2011. High-resolution interferometric monitoring of Piton de la Fournaise with TERRASAR-X and COSMO-SKYMED data. FRINGE 2011 workshop, 19-23 September 2011. ESRIN, Frascati, Italy.

Fukushima, Y., Cayol, V., Durand, P., 2005. Finding realistic dike models from interferometric synthetic aperture radar data: the February 2000 eruption at Piton de la Fournaise. J. Geophys. Res. http://dx.doi.org/10.1029/2004JB003268.

Fukushima, Y., Cayol, V., Durand, P., Massonnet, D., 2010. Evolution of magma conduits during the 1998-2000 eruptions of Piton de la Fournaise volcano, Réunion Island J. Geophys. Res. http://dx.doi.org/10.1029/2009JB007023. 
Gailler, L.-S., Lénat, J.-F., Lambert, M., Levieux, G., Villeneuve, N, Froger, J.-L, 2009. Gravity structure of Piton de la Fournaise volcano and inferred mass transfer during the 2007 crisis. J. Volcanol. Geotherm. Res. 184, 31-48.

Got, J.-L, Peltier, A., Staudacher, T., Kowalski, P., Boissier, P., 2013. Edifice strength and magma transfer modulation at Piton de la Fournaise volcano. J. Geophys. Res. http://dx.doi.org/10.1002/jgrb.50350.

Gottsmann, J., Folch, A., Rymer, H., 2006. Unrest at Campi Flegrei: a contribution to the magmatic versus hydrothermal debate from inverse and finite element modelling. J. Geophys. Res. http://dx.doi.org/10.1029/2005JB003745.

Gouhier, M, Coppola, D, 2011. Satellite-based evidence for a large hydrothermal system at Piton de la Fournaise volcano (Reunion Island). Geophys. Res. Lett. http://dx.doi.org/ 10.1029/2010GL046183.

Hurwitz, S., Christiansen, L.B., Hsieh, P.A., 2007. Hydrothermal fluid flow and deformation in large calderas: inferences from numerical simulations.J. Geophys. Res. http://dx.doi.org/ $10.1029 / 2006$ JB004689.

Iverson, R.M., 1995. Can magma-injection and groundwater forces cause massive landslides on Hawaiian volcanoes? J. Volcanol. Geotherm. Res. 66, 295-308.

Jónsson, S.P., 2002. Modeling volcano and earthquake deformation from satellite radar interferometric observations. (Ph.D. thesis). Stanford Univ., Stanford, Calif.

Jónsson, S., Zebker, H., Cervelli, P., Segall, P., Garbeil, H., Mouginis-Mark, P., Rowland S., 1999. A shallow-dipping dike fed the 1995 flank eruption at Fernandina volcano, Galapagos, observed by satellite radar interferometry. Geophys. Res. Lett. http://dx.doi.org/10.1029/1999GL900108.

Journel, A.G, Huijbregts, C., 1978. Mining Geostatistics. Academic Press (600 pp.).

Labazuy, P., 1996. Recurrent landslides events on the submarine flank of Piton de la Fournaise volcano (Reunion Island). In: McGuire, W.J., Jones, A.P., Neuberg, J. (Eds.), Volcano instability on the Earth and other planetsJ. Geol. Soc. Lond. 110, 295-306.

Le Friant, A., Lebas, E, Clément, V., Boudon, G., Deplus, C, de Voogd, B., Bachèlery, P, 2011 A new model for the evolution of la Réunion volcanic complex from complete geophysical surveys. Geophys. Res. Lett. http://dx.doi.org/10.1029/2011GL047489.

Lénat, J.-F., 2007. Retrieving self potential anomalies in a complex volcanic environment: a SP/elevation gradient approach. Near Surf. Geophys. 5, 161-170.

Lénat, J.-F., Bachèlery, P., 1990. Structure et fonctionnement de la zone centrale du Piton de La Fournaise. In: Lénat, J.F. (Ed.), Le volcanisme de La Réunion. Cent. de Rech. Volcanol, Clermont- Ferrand, France, pp. 257-296.

Lénat, JF, Vincent, P., Bachèlery, P , 1989. The off-shore continuation of an active basaltic volcano: Piton de la Fournaise (Reunion Island, Indian Ocean): structural and geomorphological interpretation from Sea Beam mapping. J. Volcanol. Geotherm. Res. $36,1-36$.

Lénat, J.-F., Bachèlery, P., Bonneville, A., Galdéano, A, Labazuy, P., Rousset, D., Vincent, P., 1990. Structure and morphology of the submarine flank of an active volcano: Piton de la Fournaise (Reunion Island, Indian Ocean). Oceanol. Acta 10, 211-223.

Lénat, J.-F., Fitterman, D., Jackson, D.B., Labazuy, P., 2000. Geoelectrical structure of the central zone of Piton de la Fournaise volcano (La Réunion). Bull. Volcanol. 62, 75-89.

Lénat, JF., Gibert-Malengreau, B., Galdéano, A, 2001. A new model for the evolution of the volcanic island of Reunion (Indian Ocean). J. Geophys. Res. 106, 8645-8663.

Lénat, J.F., Bachèlery, P., Peltier, A., 2012. The interplay between collapse structures, hydrothermal systems and magma intrusions: the case of the central area of Piton de la Fournaise volcano. Bull. Volcanol. 74, 407-421. http://dx.doi.org/10. 1007/s00445-011-0535-3.

Lundgren, P., Usai, S., 2001. Modeling surface deformation observed with synthetic aperture radar interferometry at Campi Flegrei caldera. J. Geophys. Res. 106, $19355-19366$.

Malengreau, B., Lenat, J.-F, Bonneville, A, 1994. Cartographie et surveillance temporelle des anomalies de polarisation spontanée (PS) sur le Piton de la Fournaise. Bull. Soc. Geol. Fr. 165, 221-232.

Massonnet, D, Feigl, K.L., 1998. Radar interferometry and its application to changes in the Earth's surface. Rev. Geophys. 36, 441-500.

McGuire, W.J., 1996. Volcano instability: a review of contemporary themes. Geol. Soc. Lond. Spec. Publ. 110, 1-23.

Michon, L, Saint-Ange, F, 2008. Morphology of Piton de la Fournaise basaltic shield volcano (La Réunion Island): characterization and implication in the volcano evolution. J. Geophys. Res. http://dx.doi.org/10.1029/2005JB004118.

Michon, L., Staudacher, T., Ferrazzini, V., Bachèlery, P., Marti, J., 2007. April 2007 collapse of Piton de La Fournaise: a new example of caldera formation. Geophys. Res. Lett. http://dx.doi.org/10.1029/2007GL031248.

Michon, L., DiMuro, A., Villeneuve, N., Saint-Marc, C., Fadda, P., Manta, F., 2013. Explosive activity of the summit cone of Piton de la Fournaise volcano (La Réunion island): a historical and geological review. J. Volcanol. Geotherm. Res. 263, 117-133.
Montgomery-Brown, E.K., Sinnett, D.K., Larson, K.M., Poland, M.P., Segall, P, Miklius, A 2011. Spatiotemporal evolution of dike opening and décollement slip at Kilauea Volcano, Hawai'i. J. Geophys. Res. http://dx.doi.org/10.1029/2010jb007762.

Newman, A.V, Dixon, T.H., Gourmelen, N., 2006. A four-dimensional viscoelastic deformation model for Long Valley Caldera, California, between 1995 and 2000. J. Volcanol. Geotherm. Res. 150, 244-269.

Palano, M., Gresta, S, Puglisi, G., 2009. Time-dependent deformation of the Eastern Flank of Mt. Etna: After-slip or viscoelastic relaxation? Tectonophysics 473, 300-311.

Peltier, A., 2007. Suivi, Modélisation et Evolution des processus d'injections magmatiques au Piton de La Fournaise. (Ph.D. thesis), Université de La Réunion (365 pp.).

Peltier, A., Famin, V., Bachèlery, P., Cayol, V., Fukushima, Y., Staudacher, T., 2008. Cyclic magma storages and transfers at Piton de La Fournaise volcano (La Reunion hotspot) inferred from deformation and geochemical data. Earth Planet. Sci. Lett. 270, 180-188.

Peltier, A., Bachèlery, P., Staudacher, T, 2009a. Magma transfer and storage at Piton de La Fournaise (La Réunion Island) between 1972 and 2007: a review of geophysical and geochemical data. J. Volcanol. Geotherm. Res. 184, 93-108.

Peltier, A., Staudacher, T., Bachèlery, P., Cayol, V, 2009b. Formation of the April 2007 caldera collapse at Piton de La Fournaise volcano: insights from GPS data. J. Volcanol. Geotherm Res. http://dx.doi.org/10.1016/j.jvolgeores.2008.09.009.

Pollard, D.D., Delaney, P.T., Duffield, W.A., Endo, E.T., Okamura, A.T., 1983. Surface deformation in volcanic rift zones. Tectonophysics $94,541-584$.

Pritchard, M.E., Simons, M., 2002. A satellite geodetic survey of large scale deformation of volcanic centres in the central Andes. Nature 418, 167-170.

Prôno, E., Battaglia, J., Monteiller, V, Got, J.-L, Ferrazzini, V., 2009. P-wave velocity structure of Piton de la Fournaise volcano deduced from seismic data recorded between 1996 and 1999. J. Volcanol. Geotherm. Res. 184, 49-62.

Reid, ME., 2004. Massive collapse of volcano edifices triggered by hydrothermal pressurization. Geology 32, 373-376.

Rinaldi, A.P. Todesco, M., Bonafede, M., 2010. Hydrothermal instability and ground displacement at the Campi Flegrei caldera. Phys. Earth Planet. Inter. 178, 155-161. http://dx.doi.org/10.1016/j.pepi.2009.09.005.

Rust, D., Behncke, B., Neri, M., Ciocanel, A, 2005. Nested zones of instability in the Mount Etna volcanic edifice, Sicily. J. Volcanol. Geotherm. Res. 144, 137-153.

Sambridge, M., 1999a. Geophysical inversion with a neighbourhood algorithm - I. Searching a parameter space. Geophys. J. Int. 138, 479-494.

Sambridge, M., 1999b. Geophysical inversion with a neighbourhood algorithm - IL. Appraising the ensemble. Geophys. J. Int. 138, 727-746.

Sigmundsson, F., Durand, Ph., Massonnet, D., 1999. Opening of an eruptive fissure and seaward displacement at Piton de la Fournaise volcano measured by RADARSAT satellite radar interferometry. Geophys. Res. Lett. http://dx.doi.org/10.1029/ 1999GL900055.

Staudacher, T., Ferrazzini, V., Peltier, A, Kowalski, P., Boissier, P., Catherine, P, Lauret, F. Massin, F., 2009. The April 2007 eruption and the Dolomieu crater collapse, two major events at Piton de la Fournaise (La Réunion Island, Indian Ocean). J. Volcanol. Geotherm. Res. 184, 126-137.

Stevens, N.F., Murray, JB., Wadge, G., 1997. The volume and shape of the 1991-1993 lava flow field at Mount Etna, Sicily. Bull. Volcanol. 59, 1-6.

Strang, G., 1986. Introduction to Applied Mathematics. Wellesley-Cambridge (398 pp.).

Tinard, P., 2007. Caractérisation et modélisation des déplacements du sol associés à l'activité volcanique du Piton de la Fournaise, île de La Réunion, à partir de données interférométriques. Août 2003 - Avril 2007. (PhD Thesis). Univerité Blaise Pascal, Clermont-Ferrand,

Trasatti, E., Giunchi, C., Bonafede, M., 2005. Structural and rheological constraints on source depth and overpressure estimates at the Campi Flegrei caldera, Italy. J. Volcanol. Geotherm. Res. 144, 105-118.

Urai, M., Geshi, N., Staudacher, T., 2007. Size and volume evaluation of the caldera collapse on Piton de la Fournaise volcano during the April 2007 eruption using ASTER stereo imagery. Geophys. Res. Lett. http://dx.doi.org/10.1029/2007GL031551.

Vlastélic, I., Menard, G., Gannoun, M., Piro, J.-L., Staudacher, T., Famin, V., 2013. Magma degassing during the April 2007 collapse of Piton de la Fournaise : the record of semi-volatile trace elements ( $\mathrm{Li}, \mathrm{B}, \mathrm{Cu}$, In, Sn, Cd, Re, T1, Bi). J. Volcanol. Geotherm. Res. 254, 94-107.

Welsch, B., Faure, F., Bachèlery, P., Famin, V., 2009. Microcrysts record transient convection at Piton de la Fournaise volcano (La Réunion hotspot). J. Petrol. 50, 2287-2305.

Wright, T.J., Parsons, BE., Lu, Z, 2004. Toward mapping surface deformation in three dimensions using InSAR. Geophys. Res. Lett. http://dx.doi.org/10.1029/2003GL018827. 